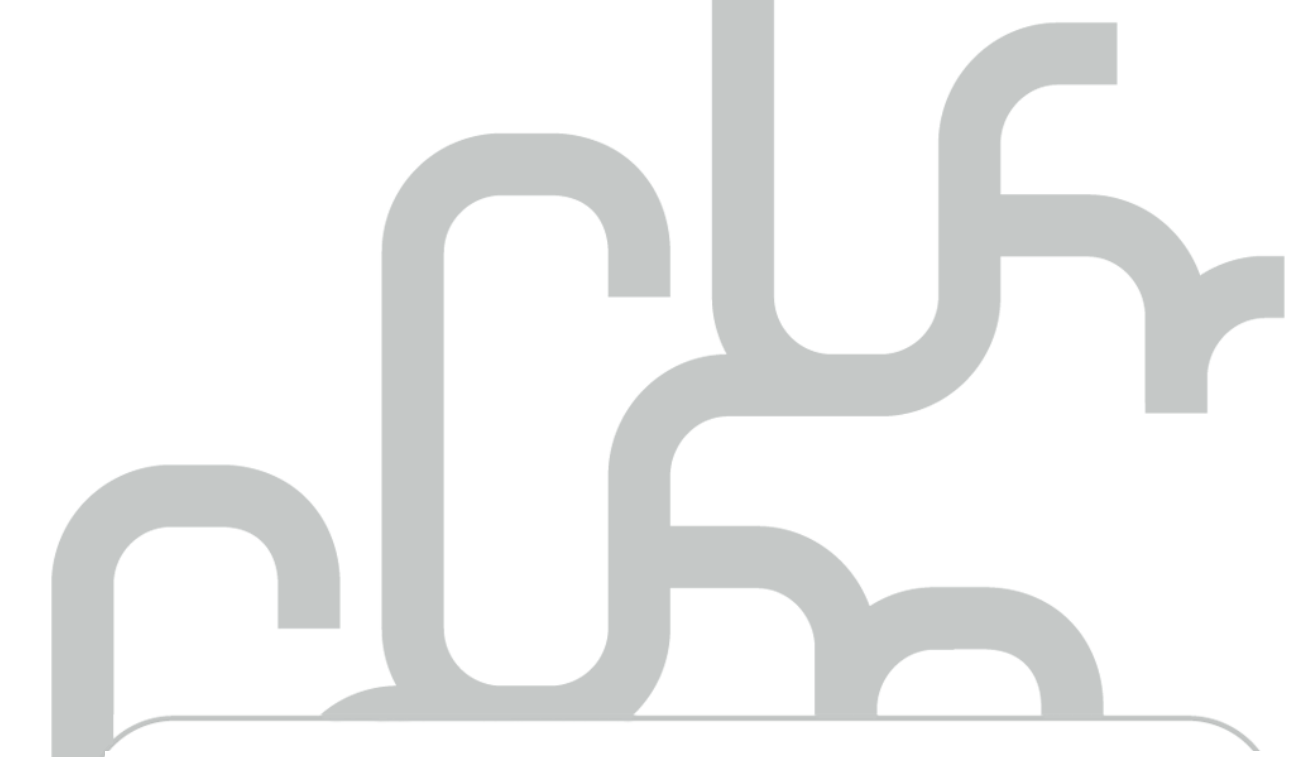

CfR working paper No. 12-02

should I stay or should I GO? former ceos as monitors

C. Andres • $\boldsymbol{\epsilon}$. fernau • $\boldsymbol{\epsilon}$. Theissen

centre for financial Research Look deeper 


\title{
Should I Stay or Should I Go?
}

\section{Former CEOs as Monitors}

\author{
Christian Andres ${ }^{\mathrm{a}}$, Erik Fernau ${ }^{\mathrm{b}}$, Erik Theissen $^{\mathrm{c}}$
}

${ }^{\text {a } W H U ~-~ O t t o ~ B e i s h e i m ~ S c h o o l ~ o f ~ M a n a g e m e n t, ~ B u r g p l a t z ~ 2, ~} 56179$ Vallendar, Germany; tel. +49 2616509 225; fax +49 2616509 229; e-mail christian.andres@whu.edu

${ }^{\mathrm{b}}$ University of Mannheim, Finance Area, L 5, 2, 68161 Mannheim, Germany; tel. +49621 181 1526; fax +49621 181 1518; e-mail: fernau@uni-mannheim.de

${ }^{\mathrm{c}}$ University of Mannheim, Finance Area, L 5, 2, 68161 Mannheim, Germany; tel. +49 621 181 1517; fax +49 621181 1518; e-mail: theissen@uni-mannheim.de

February 2013 


\title{
Should I Stay or Should I go?
}

\author{
Former CEOs as Monitors
}

\begin{abstract}
In the German two-tiered system of corporate governance, it is not uncommon for chief executive officers (CEOs) to become the chairman of the supervisory board of the same company upon retirement. This practice has been discussed controversially because of potential conflicts of interest. As a member of the supervisory board the former CEO has to monitor his successor and former colleagues, and he is involved in setting their pay. We analyze a panel covering 150 listed firms over a 10-year period. Consistent with the existence of a leniency bias, we show that firms in which a former CEO serves on the supervisory board pay their executives significantly more. We further find weak evidence that the compensation of the members of the supervisory board is also higher. Short-run event study results indicate that the announcement of the transition of a retiring CEO to the supervisory board is considered as good news. Thus, despite the increases in executive compensation we document, CEO transitions are not a cause of concern for shareholders.
\end{abstract}

JEL Classification: G30, G38

Keywords: Executive compensation, board structure, two-tiered board 


\section{Introduction}

One distinguishing feature of the German corporate governance system is the two-tiered board structure with an executive board and a supervisory board. The executive board runs the firm while the main task of the supervisory board is to monitor the executive board. The members of the supervisory board are elected by shareholders and employees (according to German co-determination laws). The supervisory board, in turn, nominates the members of the executive board and sets their pay.

A person cannot be a member of both boards simultaneously. What can and often does happen, though, is that the CEO, after retiring, becomes a member of the supervisory board. We refer to this as CEO transitions. In the majority of the cases (about $60 \%$ in our sample) a former CEO who becomes a member of the supervisory board is then elected chairman of the board. This is potentially important because the chairman of the supervisory board almost always also chairs the compensation committee.

The transition of a former CEO to the supervisory board has been discussed controversially. On the one hand the former CEO has accumulated firm and industry expertise, which should allow him to fulfill his monitoring task effectively. On the other hand he becomes the supervisor of the management team that he just left. This entails the danger of too cozy relations. The personal connection likely leads to a leniency bias, which may result in higher executive compensation. In addition, the former CEO may be reluctant to criticize or revoke decisions he took during his tenure as CEO. He may even exert pressure on his successor not to challenge the strategy or organizational structure he implemented during his tenure. In consequence, a former CEO who becomes chair of the supervisory board may impede necessary changes. 
These potential conflicts of interest have sparked regulatory change. In 2005 a provision dealing with the issue was added to the German Corporate Governance Code. ${ }^{1}$ It recommended that "it shall not be the rule" for the former CEO or a former executive board member to become chairman of the supervisory board. This provision had little practical effect. Therefore a new law was enacted and came into force in 2009. It introduced a "cooling-off period" for former executives who wish to become supervisory board members. A person who was a member of an exchange-listed firm's executive board within the past two years cannot become a member of the same company's supervisory board. ${ }^{2}$ This provision is not limited to the position of chairman (as was the case under the recommendation of the code).

It is a priori unclear whether the advantages or the disadvantages of having a former CEO on the supervisory board dominate (and, consequently, whether or not the new law can be justified on economic grounds). We therefore address the issue empirically. We construct a panel data set covering 150 German listed firms over a 10 -year period. We use this data set to analyze three questions. First, we ask whether the promotion of a former CEO to the supervisory board affects firm value. To answer this question we perform both short-term and long-term event studies. Second, we analyze whether the presence of a former CEO on the supervisory board affects the operational performance of the firm. Third, we investigate whether the level of executive compensation or the level of director compensation ${ }^{3}$ is different in firms in which a former CEO serves on the supervisory board. To this end we estimate panel regressions and perform a difference-in-differences analysis.

\footnotetext{
${ }^{1}$ The German Corporate Governance Code works according to the comply-or-explain principle. Compliance is not mandatory. Rather, firms have to publish an annual declaration of conformity that states their degree of compliance. See section 2 and Andres and Theissen (2008) for more details.

${ }^{2}$ There is an exception that is tailored to family firms. See section 2 below for details.

${ }^{3}$ We use the term "executives" for the members of the executive board and the term "directors" for the members of the supervisory board.
} 
Our findings can be summarized as follows. Executive compensation is significantly higher in firms in which a former CEO sits on the supervisory board. The effect is not only statistically significant, but also economically significant. The per capita compensation of the members of the executive board is found to be about $€ 125,000-150,000$ higher (after controlling for other variables, such as firm size) when the chairman of the supervisory board is a former CEO of the same firm. Further, executive compensation is positively related to the amount of time the former CEO and the current executives were jointly sitting on the executive board. Results with respect to director compensation are less clear. We find weak evidence in favor of increased director compensation when a former CEO chairs the supervisory board. When considered in isolation, these results support the critics of CEO transitions. However, our event study results indicate that firm value, if anything, increases when a former CEO becomes a member of the supervisory board while operational performance is not significantly affected. In summary, our findings thus do not support the conclusion that CEO transitions are disadvantageous to shareholders.

Our paper is related to several strands of the literature. First, and most importantly, it is related to some recent papers that have also analyzed the transition of former CEOs to the supervisory board of German listed corporations. Both Bermig and Frick (2010) and Grigoleit et al. (2011) analyze whether firms with a former CEO at the helm of the supervisory board have higher firm values or deliver better operational performance. While Bermig and Frick (2010) find some evidence of a negative effect, Grigoleit et al. (2011, p. 608) conclude that there is "no significant relation between supervisory board membership of former executive board members and firm performance". Grigoleit (2011) uses short-run event study methodology and concludes that the announcement of a CEO transition has no significant impact on share prices. Bresser and Valle Thiele (2008) find that the current CEO of a firm is more likely to be replaced in response to poor performance when a former CEO chairs the supervisory board. Fiss (2006) reports that executive compensation is lower in firms that have 
a former CEO at the helm of the supervisory board and that have high ownership concentration. All papers alluded to above focus on individual aspects of CEO transitions. Ours is the first paper that provides a comprehensive analysis of the economic consequences of CEO transitions. It is also the first paper to use a difference-in-differences approach to study the effects on executive compensation of CEO transitions, and it is the first paper that analyzes director compensation in addition to executive compensation.

On a more general level our paper is related to the literature on the magnitude and determinants of executive compensation (see the surveys by Murphy, 1999; Aggarwal, 2008; Frydman and Jenter, 2010; for evidence from Germany, see Schmid, 1997; Elston and Goldberg, 2003; Kaserer and Wagner, 2004; Haid and Yurtoglu, 2006). We draw on this literature to determine the set of control variables to be included in our analysis of executive compensation.

Our paper is further related to several papers that analyze the relation between executive compensation and board structure. Hallock (1997) and Core et al. (1999) report that executive compensation in US firms with reciprocally interlocking boards is higher than in other firms. Agrawal and Nasser (2012), also using US data, find that the presence of an independent director who is also a blockholder reduces executive pay. Lawrence and Stapledon (1999), on the other hand, find no evidence that the proportion of independent directors on the boards of Australian firms affects executive compensation. Fahlenbrach et al. (2010) find that the appointment of the CEO of another firm as outside director does not affect CEO compensation. Boyle and Roberts (2010) analyze a sample of New Zealand firms in some of which the CEO is a member of the compensation committee. They document higher pay increases (but not higher pay levels) and lower pay-performance sensitivity in these firms. Evans et al. (2010) discuss whether a departing CEO should be retained on the board of US 
firms. They do not, however, analyze whether this decision has implications for executive compensation.

Our paper contributes to the literature in a number of important ways. As noted above, it is the first paper that provides a comprehensive analysis of the implications of CEO transitions for firm value, operating performance, and executive compensation. We are also the first to analyze whether the amount of time the former CEO and the current executives spent together on the executive board affects executive compensation. Finally, ours is the first paper that considers the impact of CEO transitions on director compensation. As a side product of our analysis, we deliver an up-to-date analysis of the determinants of executive and director compensation in Germany. We also go beyond the existing literature by analyzing long-run performance. Specifically, we build portfolios of firms with a former CEO on the supervisory board and test for abnormal long-run performance using the Fama-French 3-factor and the Carhart 4-factor model. In addition, we calculate buy-and-hold-returns based on the market model.

Our results are important in several respects. First, they contribute to the regulatory debate about the desirability of having a former CEO on the supervisory board. Against the background of our evidence, the new law which came into force in 2009 and which impedes, or at least delays, the transition of a former CEO to the supervisory board is questionable. Second, our finding that a former CEO serving on the supervisory board exerts his influence to increase executive compensation supports the existence of a leniency bias. The result that executive compensation is increasing in the amount of time the former CEO and the current executives spent together on the executive board supports the view that stronger personal relations and common experiences increase the leniency bias. Our finding (albeit weak) that director compensation tends to be higher when a former CEO is at the helm of the supervisory board is consistent with the view that former CEOs exert their influence not only to the 
benefit of their successors and former colleagues, but also to their own benefit. Finally, on a more general level our results deliver insights into the working of a two-tiered board structure. This is particularly relevant because the introduction of the statute of the Societas Europaea (SE) allows SEs in all European Union countries, including those that formerly allowed only one-tier boards, to adopt a two-tiered board structure. The German experience with two-tiered boards may provide some guidance on the optimal organizational form.

The remainder of this paper is structured as follows. Section 2 describes the institutional setting. Section 3 develops the hypotheses. Section 4 presents the data set and some descriptive statistics. The design and results of our performance analysis are discussed in Section 5. Section 6 contains the results of our analysis of executive and director compensation, and Section 7 presents our conclusions.

\section{Institutional Environment}

This section briefly reviews the institutional background and corporate governance regulations in Germany. The German equity market is characterized by concentrated ownership structures and an inactive market for corporate control (Franks and Mayer, 2001). Consequently, monitoring by blockholders is an important corporate governance mechanism. Among these blockholders, founding families, domestic financials (banks and insurance companies), and other domestic corporations have traditionally been the most important ones. In recent years, however, bank equity ownership in non-financial firms has diminished (Dittmann et al., 2010) and foreign investors have gained importance.

To make the German corporate governance system more transparent, particularly for foreign investors, Germany introduced the Corporate Governance Code in 2002. The German Corporate Governance Code (hereafter "the code") contains recommendations and suggestions deemed to constitute "good governance." The code is updated regularly and contains sections on shareholders and the general meeting, the executive board, the 
supervisory board, cooperation between these two boards, transparency, and the reporting and auditing of annual financial statements.

Firms are not obliged to follow the recommendations of the code. However, the Stock Corporation Act (Aktiengesetz) requires that listed firms publish an annual declaration of conformity. It must contain the information that the recommendations of the code "have been and are being complied with or which of the code's recommendations are not being applied." $" 4,5$ This is referred to as the "comply-or-explain principle" and is a building block of corporate governance regulations in a large number of European and non-European countries.

The German Stock Corporation Act stipulates a two-tiered board structure with an executive board and a supervisory board. The executive board (Vorstand) is responsible for running the firm. The supervisory board (Aufsichtsrat), which is composed of shareholder and employee representatives, ${ }^{6}$ monitors the executive board, appoints and dismisses executives, and sets their remuneration. The final decision about executive compensation is made by the whole supervisory board. The decision may be prepared by a compensation committee. Usually, the chairman of the supervisory board also chairs the compensation committee. ${ }^{7}$

It is not uncommon for CEOs of German corporations to become either a member or the chairman of the supervisory board of the same company upon retirement. This "tradition" has been criticized by shareholder rights groups since it is likely that conflicts of interest arise

\footnotetext{
${ }^{4}$ This is a translation of Article 161 of the Aktiengesetz adopted from http://www.corporate-governancecode.de/eng/entsprechenserklaerung/index.html, the official homepage of the Corporate Governance Commission. Besides recommendations the code also contains suggestions. No declaration of conformity must be made with respect to suggestions.

${ }^{5}$ Even though all exchange-listed corporations are obliged to publish a declaration of conformity, companies have been very reluctant to comply with some recommendations of the code. For example, only a small minority of firms complied with the recommendation to publish executive remuneration on an individual basis (Andres and Theissen, 2008).

${ }^{6}$ According to several codetermination laws, German corporations must allow employee representatives on the supervisory board. Simply put, one-third (one-half) of supervisory board seats are filled with employee representatives in companies with more than $500(2,000)$ employees.

7 The German corporate governance code recommends that, in case a compensation committee exists, the chairman of the supervisory board shall also chair that committee. During 2003-2007, compliance rates with this recommendation were between $86 \%$ and $100 \%$ for firms included in the DAX, MDAX, or SDAX indices and exceeded 95\% for each of these indices in most years (von Werder and Talaulicar, 2007).
} 
(see section 3 for a discussion). In 2005 a provision dealing with the issue was added to the code. It recommended that "it shall not be the rule" for the former CEO or a former executive board member to become chairman of the supervisory board. As stated above, firms do not have to follow the recommendations of the code. In addition, this particular recommendation cannot be interpreted as a general ban, since it only stated that the transfer from the executive to the supervisory board "shall not be the rule." Consequently, the provision had little practical effect.

In 2009 a new law on the "appropriateness of management board compensation" (VorstAG) came into force. Among other things, the law introduced a "cooling-off period" for former executives who wish to become supervisory board members: According to paragraph 100(2) of the AktG, a person who was a member of an exchange-listed firm's executive board within the past two years cannot become a member of the same company's supervisory board. ${ }^{8}$ This provision is not limited to the position of chairman (as was the case under the recommendation of the code). Potential conflict of interest was stated as the main reason for the new rule. Our data set covers the period 1998-2007 and is thus not affected by the new law.

\section{Hypotheses}

This paper's main objective is to analyze whether the transition to the supervisory board of a retiring CEO has implications for firm value, the operating performance, or the compensation of executives or directors. As already stated in the introduction there are arguments in favor of both positive and negative effects.

\footnotetext{
${ }^{8}$ The law also contains an exception from the ban: If the suggestion to elect the former executive to the supervisory board is due to shareholders (with a quorum of $25 \%$ of votes), a former executive can directly become member of the supervisory board without taking the two-year waiting period into account. The exception was explicitly tailored to the interests of family firms, where founders or other family members should be able to monitor executives after their retirement.
} 
During his tenure a CEO accumulates firm and industry expertise and builds relations to suppliers, customers, large owners and creditors. Upon transition to the supervisory board after retirement he thus should be in a position to fulfill his monitoring task effectively and to provide valuable advice to the executive board. According to the stewardship theory of management, managers will use their expertise and their connections in the best interest of the firm. As a consequence, the appointment of a retiring CEO to the supervisory board should be regarded as good news by investors. We therefore have

Hla (Share price performance - "stewardship theory"): Share prices react positively to the announcement that a retiring CEO will become a member of the supervisory board.

If the stewardship theory holds, the appointment should also improve the operating performance of the firm. We thus have

H2a (Operating performance - "stewardship theory"): Firms with a former CEO on the supervisory board have better operating performance.

The stewardship theory essentially assumes that there are no conflicts of interest between the former CEO and the firm. This does not have to be the case. In his new role as supervisor the former CEO may be reluctant to criticize or revoke decisions he took during his tenure as CEO. He may even exert pressure on his successor (the new CEO) not to challenge the strategy or organizational structure he implemented during his tenure. In consequence, a former CEO who becomes chair of the supervisory board may impede necessary changes. The German legislator adopted such a more skeptical view. In the proposed resolution for the decision on the law on the "appropriateness of management board compensation" in parliament, it was argued that it is "alarming" that former executives are given the opportunity to constrain actions of the current executive board to correct strategic mistakes or to resolve irregularities that lead back to their time as CEO (Bundestag, 2009). 
This more pessimistic view on the role of the former CEO results in the "agency theory" counterparts of hypotheses 1a and 2a above.

$H 1 b$ (Share price performance - "agency theory"): Share prices react negatively to the announcement that a retiring CEO will become a member of the supervisory board.

H2b (Operating performance - "agency theory"): Firms with a former CEO on the supervisory board have worse operating performance.

As noted earlier, a former CEO who becomes a member of the supervisory board becomes involved in setting executive pay. This is particularly true in cases in which the former CEO is elected chairperson of the supervisory board, because the chair of the supervisory board almost always also chairs the compensation committee.

There are several arguments that suggest that executive compensation will be higher when a former CEO is on the supervisory board. The former CEO will typically have close personal relations with his former colleagues on the executive board. Out of a feeling of (excessive) loyalty to his former colleagues he may feel inclined to give in to their requests for higher compensation. In many cases, the evaluation of the performance of an executive (particularly with respect to long-term objectives) includes a subjective assessment besides objective performance measures. This is referred to as "subjective performance evaluation" (Prendergast and Topel, 1993). Prendergast (1999) points out that the principal's discretionary authority often leads to a positive bias, the so-called leniency bias. ${ }^{9}$ Giebe and Gürtler (2012) present a model in which supervisor leniency is consistent with optimal contracts under informational asymmetries in a three-tiered hierarchy-principal, supervisor, and agent, which is precisely the environment we observe in public firms in which the supervisor (i.e., the supervisory board) is not the ultimate principal (i.e., shareholders). In our context,

\footnotetext{
${ }^{9}$ The most obvious reason for a positive leniency bias lies in the fact that it is simply unpleasant for a supervisor to offer negative ratings to an agent, which is why the supervisor refrains from doing so (Prendergast, 1999). Subrahmanyam (2008) offers an alternative explanation based on the concept of social networks.
} 
personal connections between the former CEO (who is now the supervisor) and his fellow executives can lead to favoritism (Prendergast and Topel, 1996) and will most likely exacerbate the leniency bias. As a result, executives may receive higher remuneration packages in firms in which one of their former peers serves as member of the supervisory board.

Previous research (e.g. Fiss, 2006; Westphal and Zajac, 1995) has found that greater similarity between the CEO and the board results in higher pay. Fiss (2006, p. 1017) argues that "it seems appropriate to expand similarity between executives and the board to also include similar experiences." Obviously, a retiring CEO who becomes a member of the supervisory board shares many experiences with the management team. The level of similar experiences is increasing in the amount of time the retiring CEO and the current executives have been sitting on the executive board together. Therefore we do not only analyze whether the presence of a former CEO on the supervisory board per se affects executive compensation, but also whether executive compensation is increasing in the average joint board tenure of the former CEO and the current executives.

We have argued above that a former CEO may want to prevent his successor (the new CEO) from changing the strategy or organizational structure the retiring CEO implemented during his tenure. Granting higher remuneration may be a component of an implicit contract towards this objective.

The aforementioned arguments lead to our third and fourth hypothesis.

$H 3$ (executive compensation - role dummy): The compensation of the members of the executive board is higher when a former CEO is a member (or the chairperson) of the supervisory board. 
$H 4$ (executive compensation - joint tenure): The compensation of the members of the executive board is increasing in the time the retiring CEO and the current executives have been sitting on the executive board together.

If a former $\mathrm{CEO}$ exerts influence to increase the compensation of the members of the executive board after retiring from the board, he will not directly benefit from this activity. $\mathrm{He}$ thus may also use his influence on the compensation process to lobby for an increase in the remuneration of the members of the supervisory board. Further, the former CEO may be thankful for having been elected into the supervisory board ${ }^{10}$ and may, therefore, lobby for higher director compensation out of a feeling of reciprocity towards the other members (as also argued by Bebchuk and Friend, 2005 in a related context).

However, changes in the remuneration of the supervisory board require the shareholders' consent. Consequently, any proposal aimed at increasing the compensation of supervisory board members must be made public prior to the shareholders' meeting and may thus attract the attention of shareholders and the general public. It is an empirical question whether or not a newly appointed supervisory board chairman will take this risk. To answer it, we test an additional hypothesis.

H5 (director compensation): The compensation of the members of the supervisory board is higher when a former CEO is a member (or the chairperson) of the supervisory board.

\section{Data and Descriptive Statistics}

Our analysis of the transfer of CEOs to the supervisory board is based on all firms included in the DAX, MDAX, or SDAX indices as of December 31, 2002 for the sample period 19982007. The focus of our study is twofold: First, we analyze whether the promotion of a former

\footnotetext{
${ }^{10}$ Formally the former CEO will be elected by the shareholders' meeting. However, the supervisory board is very influential in proposing candidates for the board.
} 
CEO to the supervisory board affects firm value and operating performance. Second, we investigate the influence that a former CEO who joined the supervisory board upon retirement may have on the level of executive and director compensation.

To address the first issue, we focus on CEO turnover events. During our sample period, we identify a total of $167 \mathrm{CEO}$ transitions. When analyzing the performance implications of the promotion of a former CEO to the supervisory board, we need to take into account that the decision to offer a former CEO a seat on the supervisory board is most likely not random. An executive who is fired due to an unsuccessful time as CEO will most certainly not be asked to become a member of the supervisory board. Therefore, when constructing a control group of firms in which the CEOs are not transferred to the supervisory board, we want to make sure that we do not compare a group of successful CEOs to a sample of CEOs who failed. We therefore exclude all cases in which a CEO was fired (58 observations) and examine only cases in which a CEO stepped down voluntarily, usually because he reached retirement age. To identify cases of (un)forced turnover, we analyze press releases as well as additional news coverage of the turnover. Due to a lack of sufficient share price information for two firms, our initial sample consists of 107 unforced CEO turnover events. In 59 cases (55\%), the CEO becomes member of the supervisory board, in the remaining 48 cases $(45 \%)$ the CEO steps down and leaves the firm.

Panel A in Figure 1 shows the frequency of these two constellations for each year of our sample period. For the group of CEO transitions to the supervisory board, Figure 1 further distinguishes between cases where the former CEO becomes the chairman of the supervisory board or an ordinary board member. The frequency of CEO transitions increases more or less steadily until 2003 (14 CEO transitions) and then decreases in the subsequent period 20042007. 
In order to investigate differences in the level of executive or director compensation in firms with and without a former CEO on the supervisory board, we construct a panel data set with additional control variables covering these 150 firms over the sample period 1998-2007. Missing data items reduce the size of our initial panel data set to 1,405 firm-year observations. We gather data on the composition of executive and supervisory boards for all sample firms over the period 1998-2007 from the Hoppenstedt Aktienführer. In addition, we collect information on the composition of executive boards for the years 1982, 1985, and 1987-1997.

Based on these data, we determine for each firm year whether the chairman or any member of the supervisory board had previously been the CEO of the firm. We define three dummy variables. The first is set to one for all firm years in which the chair or any member of the supervisory board is a former CEO of the firm, and zero otherwise. The second (third) is set to one for all firm years in which the former CEO is the chairman (an ordinary member) of the supervisory board, and zero otherwise. ${ }^{11}$ During our sample period the number of former CEOs on supervisory boards increased from 30 in 1998 (25.21\% of observations in that year) to 42 in 2007 (31.58\%) with a high of 46 in 2005 (31.94\%). Over the whole sample period, 62 firms $(41.33 \%$ of the firms in our sample) had a former CEO on the supervisory board of the same firm for at least one year. It is noteworthy that there is not only cross-sectional variation in the data, but also a high degree of longitudinal variation. Out of 62 firms that have a former CEO on the supervisory board at some point in time, only 14 firms have a former CEO in this position over the entire sample period. Panel B in Figure 1 depicts the frequency of the three different constellations for each year of the sample period.

\section{[Insert Figure 1 about here]}

\footnotetext{
${ }^{11}$ For 29 firm-year-observations, the chairman and an ordinary supervisory board member are former CEOs of the same firm. As we are interested in differences between these two types of CEO transitions to the supervisory board, we set the dummy for "Former CEO is chairman of the supervisory board" to one and the dummy for "Former CEO is an ordinary board member" to zero for these firm-year-observations.
} 
During most of our sample period, firms were not required to publish executive compensation on an individualized basis. ${ }^{12}$ The commercial code did, however, require the disclosure of the aggregate compensation of the members of both boards. We collected this data from the annual reports for the fiscal years ending in 1998-2007 and combined it with information on the number of board members to obtain the per capita compensation of the board members.

As mentioned above, concentrated ownership potentially leads to closer monitoring, since large blockholders have both the incentive and power to effectively control management. Hartzell and Starks (2003) find a negative relation between institutional ownership concentration and executive compensation. Similar findings for the German market are reported in Elston and Goldberg (2003), Kaserer and Wagner (2004), and Haid and Yurtoglu (2006). In addition, Bertrand and Mullainathan (2001) find that executives in firms without a large external blockholder tend to be rewarded for luck.

To account for the relation between ownership structure and executive compensation, we collected data on all common and preferred shareholdings exceeding the threshold of 5\% from the Hoppenstedt Aktienführer. ${ }^{13}$ We construct two dummy variables to distinguish closely held firms from widely held firms. A firm is said to be closely held according to a $50 \%(25 \%)$ threshold if the largest shareholder holds at least $50 \%(25 \%)$ of the voting equity. ${ }^{14}$ We follow the classification method proposed by da Silva et al. (2004) to determine the controlling shareholder at the ultimate level for each firm-year. The ownership data in

\footnotetext{
${ }^{12}$ Only from 2006 onward did the law require the individualized disclosure of the compensation of the members of the executive board (but not of the members of the supervisory board) and its composition (fixed and variable parts). Prior to 2006 the German code recommended individual disclosure, but only a minority of firms complied.

${ }^{13}$ During our sample period, shareholdings had to be registered with the German Financial Supervisory Authority (BaFin) when they exceeded the threshold of 5\%. In some but not all cases, shareholdings of less than $5 \%$ were also reported in Hoppenstedt. For reasons of data consistency, we excluded these shareholdings.

${ }^{14}$ In addition to shareholder concentration, the identity of the controlling shareholder is a potentially important determinant of executive compensation. Identification of the controlling shareholder is complicated by the fact that German corporations often have complex control structures (Franks and Mayer, 2001). For example, a family can own a holding company that then owns the majority of a listed firm. If we only considered ownership at the first tier, we would misclassify the firm as being controlled by the holding company while it is in fact family controlled (Franks et al., 2012). Thus, we focus on ultimate ownership to identify the identity of the largest shareholder.
} 
Panel A of Table 1 is based on this methodology. 39\% (63\%) of the firms in our sample are classified as closely held based on a $50 \%(25 \%)$ threshold. ${ }^{15}$ We also collected the percentage of shares held by the CEO, the chairman of the board, as well as by the entire executive and supervisory board, respectively. The fraction of shares held by the members of the executive or supervisory board exceeds a 50\% (25\%) threshold for 21\% (38\%) of all firm-years.

Table 1 also describes the ownership characteristics separately for firms with and without a former CEO on the supervisory board. The results suggest that widely held firms are almost equally likely to have a former CEO on the supervisory board, but are more likely to have a former CEO as chairman of the supervisory board: 176 (133) of 234 firm-years $(75 \%(57 \%))$ with a former CEO as chairman of the supervisory board are widely held based on a $50 \%$ $(25 \%)$ threshold, whereas the corresponding proportion of widely held firms is lower in the whole sample (61\% (36\%) using a 50\% (25\%) threshold).

The existence of controlling shareholders entails the risk of conflicts of interest between large and small shareholders. However, a second large shareholder can mitigate these conflicts and prevent the controlling shareholder from expropriating minority shareholders. To capture this effect, we follow the approach of Gugler and Yurtoglu (2003) and divide our sample into "checked" and "unchecked" firms. Unchecked firms are those without a second large shareholder holding more than $5 \%$ of the voting shares, whereas checked firms are closely held and have at least one additional shareholder holding more than $5 \%$ of the votes. According to this definition, $12 \%(29 \%)$ of the firm-year observations in our sample are classified as checked based on a 50\% (25\%) threshold.

In accordance with previous studies (Boyd, 1996; Gorton and Schmid, 2004; Linn and Park 2005), we also control for firm size, board and CEO characteristics, firm performance, growth

\footnotetext{
${ }^{15}$ Among these firms, most companies are owned by families (69\%), followed by other shareholders $(21 \%)$, industrial $(6 \%)$, and financial firms (4\%). The results are similar for a $25 \%$ threshold.
} 
opportunities, and codetermination in our panel regressions. ${ }^{16}$ Information on codetermination was collected from Hoppenstedt Aktienführer. All other information was taken from Datastream. For our panel regressions with director compensation as independent variable, we also control for the effort associated with a board membership. A reasonable proxy for the effort associated with a board membership is the number of board meetings. We obtained data on the number of board meetings from the annual reports.

Descriptive statistics and detailed definitions of these variables are presented in Panel B in Table 1. The means of most control variables are very similar for firms with and without a former CEO on the supervisory board. However, firms with a former CEO as chairman of the supervisory board are on average larger and firms with a former CEO as ordinary supervisory board member exhibit a higher share price performance and higher percentage of shares held by the supervisory board.

[Insert Table 1 about here]

\section{Performance Analysis}

\section{A. Event Studies}

We begin our empirical analysis by examining the market reaction to CEO turnover announcements. Over the sample period from 1998-2007, we identify a total of 167 turnover announcements. As hypothesized above, the transition of a former CEO to the supervisory board of the same firm might either be perceived as positive $(H 1 a)$ or negative $(H 1 b)$ by market participants. We use the procedure described in the previous section to exclude all cases in which a CEO was fired (58 observations) and examine only cases in which a CEO stepped down voluntarily, leaving us with a sample of 107 announcements. ${ }^{17}$ We exclude

\footnotetext{
${ }^{16}$ Codetermination is defined as the number of employee representatives on the supervisory board divided by the total number of supervisory board members.

${ }^{17}$ Two observations are dropped due to a lack of share price information.
} 
cases of forced CEO turnover as they will likely lead to a positive market reaction and will therefore bias the results of our control group of CEOs who leave the firm.

We follow a standard event study approach (Brown and Warner, 1985), and estimate marketmodel parameters over the period from $\mathrm{t}=-250$ to $\mathrm{t}=-31$ (relative to the announcement day $\mathrm{t}=0$ ). Our event period covers the 60 day period from $\mathrm{t}=-30$ to $\mathrm{t}=+30$. Statistical significance is tested using a t-test, the standardized cross-sectional t-statistic proposed by Boehmer et al. (1991) and the Corrado (1989) rank test.

For the full sample of unforced turnover events, we find announcement returns that are close to zero and statistically insignificant (see Panel A of Table 2). This implies that the information of an unforced CEO turnover per se is not regarded as value relevant information on average. However, a more detailed analysis reveals significant differences in the market reaction, depending on whether the CEO will stay as member of the supervisory board or leave the firm. Panel B of Table 2 presents cumulative abnormal returns for CEO turnover announcements in which the CEO leaves the firm. The reaction to the announcement of CEO transitions to the supervisory board is presented in Panel C. These results show negative and significant announcement returns for cases in which a departing CEO will not become member of the supervisory board. Depending on the event window, we document a reaction in the range of $-0.87 \%$ (announcement day $[\mathrm{t}=0]$, significant at the 0.05 -level) and $-5.31 \%$ (event window $[-30 ;+30]$, significant at the $0.10-$ level). For the event windows that are close to the announcement date, we find a negative market reaction of up to $-1.80 \%[0 ;+5]$. These findings indicate that the unforced departure of CEOs (i.e. CEOs who were not forced out of their jobs) is seen as a loss of a valuable resource by shareholders. In line with these results, we find positive and significant announcement period returns for cases in which a CEO changes to the supervisory board upon retirement (and thus his expertise is retained in the firm). Panel $\mathrm{C}$ shows positive and statistically significant abnormal returns for the three 
longest announcement periods. Within the event windows from $[-30 ;+30]$ and $[-10 ;+30]$, the average cumulative abnormal return is found to be $+5.30 \%$ and $+4.92 \%$, respectively. Announcement returns are lower (and statistically insignificant) for shorter time periods surrounding the event date, but never negative.

\section{[Insert Table 2 about here]}

In sum, our short-term event study provides evidence in favor of hypothesis Hla. On average, market participants seem to attribute value to the expertise of a retiring CEO and accordingly regard the announcement of a transition to the supervisory board as good news. Conversely, firm value is reduced when retiring CEOs say goodbye. These results are mostly in line with earlier findings by Grigoleit (2011). We analyze a series of alternative specifications to test the robustness of our results. ${ }^{18}$ First, we examine whether the future role of the former CEO on the supervisory board (i.e. chairman or ordinary board member) is systematically related to announcement returns. We find qualitatively similar abnormal returns for the two groups. Second, we separate all events into two categories, depending on whether the decision of the CEO to leave or stay was announced at the same time as the retirement or at a later stage. Again, we do not find substantial differences between the two groups. Finally, we test whether the announcement of other potentially value-relevant information affects abnormal announcement returns. Controlling for confounding events, we are left with a sample of 99 CEO transitions. Abnormal returns for this subsample are again very similar to those reported in Table 2.

In addition to the short-run event study, we examine the long-run market performance following CEO turnover events. In particular, we estimate the abnormal performance for a portfolio of sample firms with a former CEO on the supervisory board for up to 12 months following the month of change. As before, we consider all CEO turnover events, cases in

\footnotetext{
18 The results of these robustness tests are not tabulated, but available upon request.
} 
which the CEO leaves the firm, and cases in which a former CEO becomes member of the supervisory board. We use the Fama-French 3-factor and the Carhart 4-factor models for the calendar-time approach and the market-model for the buy-and-hold approach. Factor information for the German market is obtained from the Centre for Financial Research Cologne. ${ }^{19}$

In contrast to the results presented above, we do not find significant abnormal returns for the long-run event study. As can be seen in Table 3 this holds for virtually all specifications, independent of the time window or normal return model used. For the calendar-time approach, we document alpha coefficients that are in line with the results of the short-run event study (Panels A and B of Table 3). For firms with CEOs who leave the firm, the alpha coefficient is negative. For firms in which the CEO changes to the supervisory board, the coefficient is found to be positive. In both cases, however, the reported t-statics are not statistically significant at conventional levels. Likewise, the market model yields abnormal buy-and-hold returns that are not statistically different from zero. The only exception is the subsample of firms in which a retiring CEO leaves the firm. However, we find negative and significant abnormal returns only for the two-months time window (significant at the 0.10 level). For most time periods, we again find abnormal returns that go in the expected direction, but are not statistically significant.

[Insert Table 3 about here]

\section{B. Operating Performance}

As argued above, we expect former CEOs who serve on the supervisory board to also affect operating performance. This effect can either be positive $(H 2 a)$ or negative $(H 2 b)$ depending on whether potential benefits - former CEOs act as stewards of the firm and hence support their successors with their firm and industry expertise - outweigh potential agency costs

\footnotetext{
${ }^{19}$ A detailed description of the data can be found in Artmann et al. (2012).
} 
(impeding necessary changes, too cozy relations between former and new CEO). In the following, we compare the operating performance of firms with former CEOs on their supervisory boards with firms in which CEOs leave the firm (voluntarily) using a differencein-difference approach.

In the analysis, we use the same sample as described in section A, but lose a few observations due to missing data. Operating performance is measured as return on assets (ROA) and return on equity (ROE). We examine both "raw" operating performance (measured as the average ROA and ROE in years $\mathrm{t}-2$ and $\mathrm{t}-1$ (relative to the turnover event) and in years $\mathrm{t}+1$ and $\mathrm{t}+2$ ) and "excess" operating performance. For the latter approach, we follow Fahlenbrach et al. (2011) and calculate excess performance relative to a group of control firms matched on industry, size, and prior performance..$^{20}$

Results of the difference-in-difference analysis are displayed in Table 4. As can be seen from Panel A, we do not find any significant differences in terms of excess operating performance between the two groups. The analysis of changes in raw operating performance (Panel B) shows weak evidence for a better performance of firms in which a former CEO is transferred to the supervisory board. However, the difference only holds for ROE as performance measure and is only statistically significant at the 0.10 -level. Results of additional tests that take the position of the former CEO on the supervisory board (i.e. chairman or ordinary member) into account lead to qualitatively very similar results. ${ }^{21}$

[Insert Table 4 about here]

These (non-)results are somewhat contradictory to those of the short-run event study. A possible explanation is that changes in operating performance only reflect cash flow information, whereas the event study abnormal return also reflects changes in the firm's cost of capital (i.e. discount rate news).

\footnotetext{
${ }^{20}$ See Fahlenbrach et al. (2011), section 2.2 for details.

${ }^{21}$ Results not tabulated, but available upon request.
} 


\section{Executive and Director Compensation}

We begin our compensation analysis by examining the time pattern for director and executive compensation (see Panel A of Table 5). Per capita director compensation during our sample period amounted to $€ 43,853$ per year. Over our sample period, the average director compensation increased from a low of $€ 30,757$ in 1998 to $€ 60,437$ in 2007 . This corresponds to an increase of $96.5 \%$, or a compound annual growth rate of $7.8 \%$. Per capita executive compensation is more than 20 times higher than per capita director compensation $(€ 944,344$ compared to $€ 43,853)$. The time pattern is similar. Average executive compensation increased by $124.0 \%$ over our sample period, which corresponds to a compound annual growth rate of $9.4 \%$.

As argued before, we expect a higher director and executive compensation for firms with a former CEO on the supervisory board $(H 3, H 4, H 5)$. The means, medians and standard deviations of director and executive compensation are displayed in Panel B of Table 5. We also test for significant differences between the means and medians of firms with a former CEO on the supervisory board (or with a former CEO as chairman of the board/ordinary board member, respectively) and firms without a former CEO serving on the supervisory board. We observe significantly higher executive and director compensation for firms with a former CEO on the supervisory board. The results further suggest that these differences are more pronounced for firms with a former CEO as chairman of the supervisory board. ${ }^{22}$ Overall, the univariate analysis provides first evidence in favor of our hypotheses $\mathrm{H3}, \mathrm{H} 4$ and H5.

\section{[Insert Table 5 about here]}

The empirical literature has identified a number of factors that have a significant impact on executive (and director) compensation. We therefore estimate the following multivariate

\footnotetext{
${ }^{22}$ The difference in means and medians or firms with a former CEO as ordinary board member and those without a former CEO on board are statistically insignificant for executive compensation.
} 
panel regression model for our analysis of the determinants of director and executive compensation:

$$
\mathrm{y}_{\mathrm{it}}=\alpha+\beta(\text { Former CEO on board })+\gamma(\text { control variables })+\tau(\text { year dummies })+\varepsilon_{\mathrm{it}}
$$

where $y_{i t}$ is our measure of per capita compensation. The presence of a CEO on the supervisory board is captured in four different ways (resulting in the four models displayed in Tables 6). In models (1) and (3) we include a dummy variable that is set to one when a former CEO is a current member of the supervisory board. In models (2) and (4) we include two dummy variables. The first dummy is set to one when a former CEO acts as an ordinary member (but not as the chair) of the supervisory board. The second dummy is set to one when a former CEO is the current chair of the supervisory board. Of all firm-years in which a former CEO acts as director of the same firm, about $61 \%$ are cases in which the former CEO is the chairman of the supervisory board. In models (5) to (8) we replace the dummies by continuous variables that measures the average time (measured in years) the former CEO was sitting on the executive board jointly with the current executive board members. We refer to this variable as "joint tenure". The larger its value the more intense will be the personal relation between the CEO and the current executives, and the larger will be the set of joint experiences they share. In models (5) and (7) we estimate one slope coefficient for all cases in which a former CEO sits on the supervisory board. In models (6) and (8) we estimate different slope coefficient for cases in which the former CEO is an ordinary member or the chair of the supervisory board, respectively.

As control variables we include firm size (measured by either the log of total assets or the log of the market capitalization ${ }^{23}$ ), the size of the executive (supervisory) board (measured as the $\log$ of the number of executives (supervisory board members)), CEO tenure (number of years on the executive board), codetermination, accounting performance (return on assets, defined

\footnotetext{
${ }^{23}$ In the tables we report the results obtained when using the log of market capitalization as our size measure. Results are similar when we use the log of total assets instead. We also included leverage as an additional control variable. Again the results were similar to those reported in the paper.
} 
as earnings before interest and taxes over total assets), abnormal share price performance (measured over one year and index-adjusted using the CDAX performance index), as well as Tobin's Q (defined as the market value of equity plus the book value of debt over the book value of total assets). In our regressions with per capita director compensation as the dependent variable we include the number of board meetings as additional control variable. Finally, we include a dummy variable for each year of the sample period. In our baseline specification, the ownership structure is captured by two dummy variables (largest shareholder holds more than $50 \%^{24}$; checked or unchecked).

We employ the fixed effects estimator in all regressions because a Hausman test indicates that the regressors are correlated with the error term. We test for serial correlation and heteroskedasticity using the test procedures proposed by Baum (2001) and Drukker (2003). ${ }^{25}$

\section{A. Executive Compensation}

Tables $6 \mathrm{~A}$ and $6 \mathrm{~B}$ report the results of fixed effects regressions with per capita executive compensation as the dependent variable (expressed in thousands of Euros). They indicate that, in line with hypothesis 3 , having a former CEO in the position of chairman of the supervisory board of the same firm has a significantly positive effect on the level of executive compensation. Per-capita executive compensation is higher by more than $€ 125,000$ (model 1) or $€ 145,000$ (model 3) when a former CEO is on the executive board. The effect is even stronger ( $€ 127,000$ and $€ 151,000$, respectively) when the former CEO chairs the supervisory board.

The results of models (5) to (8) provide evidence in favor of hypothesis 4 . They indicate that executive compensation increases in the joint tenure of the former $\mathrm{CEO}$ and the current

\footnotetext{
${ }^{24}$ In additional regressions we use an alternative definition based on a $25 \%$ threshold. We further re-estimate our models using the shareholdings of the largest shareholder instead of a dummy variable. Finally, we also estimate models in which we include dummy variables that control for the identity of a controlling shareholder (family, industrial firm, financial institution, other). The results of all these specifications are qualitatively and quantitatively similar to those reported in the paper. Tables are available upon request.

${ }^{25}$ The test procedure developed by Baum (2001) is based on Greene (2000, p. 598), and Drukker's (2003) method follows Wooldridge (2002, pp. 282-283).
} 
executives on the executive board. The effect is driven by those cases in which the former CEO is the chair of the supervisory board.

With respect to the control variables, we find that per-capita executive compensation is increasing in firm size. This is consistent with previous findings (see Schmid, 1997 for evidence from Germany and Murphy, 1985; Jensen and Murphy, 1990; Gabaix and Landier, 2008 for international evidence). Surprisingly, per-capita executive compensation is, if anything, negatively related to Tobin's Q. It is further decreasing in the size of the executive board and increasing in CEO tenure. The latter finding is consistent with results reported in Hill and Phan (1991) and Bertrand and Mullainathan (2001).

Previous papers found that executive compensation is lower in firms with concentrated ownership (see Hartzell and Starks, 2003 for the US; Sapp, 2008 for Canada and Schmid, 1997; Elston and Goldberg, 2003 and Kaserer and Wagner, 2004 for Germany). Our results point in the same direction but fall short of being significant. The coefficient on the dummy variable which identifies firms that have a dominating shareholder is negative in all eight models, with t-statistics ranging from 1.42 to 1.61 . The existence of a second large shareholder, on the other-hand side, has a positive and significant impact on executive compensation. The equity stake held by executive directors has no impact on executive compensation. On the other hand, the stake held by members of the supervisory board is significantly positively related to per-capita executive compensation.

\section{[Insert Table 6 about here]}

Since our results indicate higher pay levels for executives in firms with a former CEO as chairman of the supervisory board, we also expect a significant increase in executive compensation at the time when a CEO steps down and becomes a member of the supervisory board. To test this hypothesis we perform a difference-in-differences analysis around CEO turnovers. 
Our treatment group consists of CEOs who step down and become members of the supervisory board of the same firm. We analyze three treatment groups, (1) all cases in which a departing CEO becomes a member of the supervisory board, (2) only cases in which the departing CEO becomes the chairman of the supervisory board and (3) only cases in which the departing CEO becomes an ordinary member of the supervisory board. These CEOs usually step down because they have reached retirement age. We construct a control group that consists of unforced CEO turnovers (as defined previously) but only contains cases in which the departed CEO did not become a member of the supervisory board. A control group that also includes forced CEO turnovers would be inappropriate. The control group is the same for all three treatment groups described above.

We want to test whether per-capita executive compensation changes significantly when a departing CEO becomes a member of the supervisory board. To this end we compare the average per-capita compensation in the two years prior to the CEO turnover to the average per-capita compensation in the five years after the turnover. The year of the turnover is discarded. We use a five-year average after the turnover because the typical term of an executive's contract in Germany is five years. It may thus take up to five years until the contracts of all executives have been renewed.

\section{[Insert Table 7 about here]}

Panel A in Table 7 shows the results of the difference-in-differences analysis. Per-capita executive compensation in the treatment groups increase by about $€ 540,000$. The increase is remarkably similar in the three treatment groups. The increase in the control group is about $€ 280,000$. The difference, although large, is not statistically significant. This may be due to the fact that the analysis so far includes neither the control variables introduced above, nor firm or year fixed effects. We therefore estimate the following regression model using the fixed effects estimator: 


$$
\mathrm{y}_{\mathrm{it}}=\alpha+\beta(\text { post })+\gamma(\text { post*treatment })+\delta(\text { control variables })+\tau(\text { year dummies })+\varepsilon_{\mathrm{it}}
$$

$y_{i t}$ is our measure of per-capita executive compensation. Treatment is a dummy variable that is equal to one (for the pre- and the post-periods) if the former CEO becomes a member of the supervisory board in the post-period, and zero otherwise. Post*treatment is our difference-indifferences estimator. It captures the difference between the change in per capita executive pay from the pre- to the post-period between the treatment and control groups. The results are shown in Table 8. Consistent with the descriptive results shown in Table 7 above, the

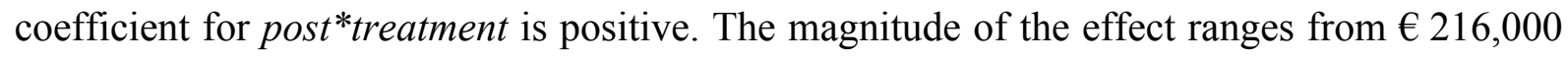
in those cases in which the departing CEO becomes an ordinary member of the supervisory board to $€ 300,000$ in those cases in which he becomes the chair. In this latter case the effect is statistically significant at the $5 \%$ level. This is consistent with the results in Table 6 above. There we also documented that the effect of the presence of a former CEO on the supervisory board is stronger when the former CEO is at the helm of the board.

Thus, even after controlling for firm and year fixed effects and control variables known to impact executive compensation, the increase in executive compensation is significantly higher around CEO turnovers in which a former CEO transitions to the supervisory board.

[Insert Table 8 about here]

Summarizing our results on executive compensation, we find evidence in support of hypotheses $H 3$ and $H 4$. When a former CEO serves as chairman of the supervisory board of the same firm, per capita executive compensation is higher by an economically significant amount. We also find that per-capita executive compensation is increasing in the time the former CEO spent on the executive board together with the current executives of the firm. This is consistent with the existence of a leniency bias. The difference-in-differences analysis confirms the results. When a former CEO becomes the chairman of the supervisory board upon retirement, we observe a significant increase in per capita executive compensation 
relative to a control group of firms that do not transfer their retiring CEO to the supervisory board.

\section{B. Director Compensation}

Table 9 contains our regression results with per capita director compensation as the dependent variable. The set of explanatory variables is similar to that used in Table 6 . We add the number of board meetings and replace the size of the executive board by the size of the supervisory board. We further exclude CEO tenure because it is not obvious that CEO tenure should be related to the compensation of the members of the supervisory board. We capture the presence of a CEO on the supervisory board in two different ways. In models (1) and (3) we include a dummy variable that is set to one when a former CEO is a current member of the supervisory board. In models (2) and (4) we include two dummy variables. The first dummy is set to one when a former CEO acts as an ordinary member (but not as the chair) of the supervisory board. The second dummy is set to one when a former CEO is the current chair of the supervisory board. ${ }^{26}$

The results indicate that a former CEO serving as ordinary member of the supervisory board does not affect the level of director compensation. When the former CEO chairs the supervisory board, however, per capita director compensation is significantly (at the $10 \%$ level) higher than in firms without a former CEO on the board. We thus find at least partial support for hypothesis 5 . We further find that director compensation increases in firm size. All other control variables are insignificant. We also note that the explanatory power of the model is much lower than that of the model for executive compensation discussed above.

[Insert Table 9 about here]

\footnotetext{
${ }^{26}$ We do not include the "joint tenure" variable because it is not plausible that the compensation of the members of the supervisory board depends on how long one of its members (the former CEO) sat on the executive board together with the current executives.
} 
As in the previous section, we perform a difference-in-differences analysis of the change in director compensation around unforced CEO turnover. Descriptive results are included in Panel B of Table 7. The results of fixed effects regressions (including the same control variables as before ${ }^{27}$ ) are displayed in Table 10. The coefficient of the differences-indifferences estimator is positive in all cases but is insignificant. Thus, in contrast to the results on executive compensation we do not find a significantly different increase in director compensation between the treatment and control groups around unforced CEO turnover.

[Insert Table 10 about here]

In summary, the evidence in favor of hypothesis 5 is weak. Per-capita director compensation is higher in firms in which a former CEO chairs the supervisory board. The difference-indifferences analysis does not confirm this finding, however. It yields positive but insignificant estimates.

We offer a potential explanation for the weak results. If a former executive who is now a member or the chair of the supervisory board exerts his influence to increase the compensation of the members of the supervisory board, he is effectively increasing his own pay. This may well be interpreted as self-dealing by shareholders and the public. One such case occurred during our sample period and attracted a lot of attention. Former Lufthansa CEO Jürgen Weber became chairman of the supervisory board right after stepping down as CEO. In one of the first board meetings, the new supervisory board proposed a resolution to double the base salary of all members of the supervisory board and to triple the salary of the chairman (which the annual general meeting approved). These decisions led to an outcry in the German public and the media accused the supervisory board of self-dealing at the expense of employees and shareholders (Spiegel, 2003). As a reaction, Mr. Weber decided to donate his pay raise as chairman to charity. With regard to our hypothesis, the public attention to Mr.

\footnotetext{
${ }^{27}$ Please note that the number of board meetings is not yet included. We will include it in the next version of the paper.
} 
Weber's actions may imply that former executives are more reluctant to raise their own salary and the salary of the supervisory board in general due to the risk of being accused of selfdealing.

\section{Conclusion}

CEO transitions have been discussed controversially. While proponents stress that the firm and industry expertise of former CEOs make them good monitors and valuable advisors, the critics point at various conflicts of interest and their potentially negative consequences. Based on a panel of 150 German firms, this paper provides evidence that executive pay is (statistically and economically) significantly higher when a former CEO is a member or the chairman of the supervisory board. The per capita compensation of the members of the executive board is higher by about $€ 125,000-150,000$ (after controlling for other variables, such as firm size) when the chairman of the supervisory board is a former CEO of the same firm. In terms of total executive compensation, executive board members with a former CEO as chairman of the supervisory board earn about $€ 675,000-800,000$ more as a group. Using difference-in-differences estimators, we find that per capita executive compensation increases by about $€ 300,000$ when a retiring CEO becomes the chairman of the supervisory board. We find weak evidence in favor of an increase in director compensation. We argue that the effect is weak because the former CEOs on the supervisory board me be afraid of allegations of selfdealing.

Our short-run event study results imply that the stock market considers the announcement of a CEO transition as good news. However, neither the long -run event study not the analysis of operating performance yield significant results.

In summary, we can conclude that CEO transitions, despite the fact that they are associated with higher executive compensation, are not a cause of concern for shareholders. 
Consequently, the new law which came into force in 2009 and which aims at preventing, or at least delaying, CEO transitions cannot be justified on the grounds of shareholder protection. 


\section{References}

Aggarwal, R. K., 'Executive compensation and incentives', in E. Eckbo, ed, Handbook of Corporate Finance, Vol. 2, (North-Holland, 2008), pp. 497-538.

Agrawal, A. and Nasser, T., 'Blockholders on boards and CEO compensation, turnover and firm valuation', Working Paper (University of Alabama, Kansas State University, 2012).

Andres, C. and Theissen, E., 'Setting a fox to keep the geese - Does the comply-or-explain principle work?', Journal of Corporate Finance, Vol. 14, 2008, pp. 289-301.

Artmann, S., Finter, P., Kempf, A., Koch, S. and Theissen, E., 'The Cross-Section of German Stock Returns: New Data and New Evidence', sbr-schmalenbach business review, Vol. 64, 2012, pp. 20-43.

Baum, C. F., 'XTTEST3: Stata module to compute modified Wald statistic for groupwise heteroskedasticity', Stata Journal, Vol. 1, 2001, pp. 101-104.

Bebchuk, L. A. and Fried, J. M., 'Pay Without Performance: Overview of the Issues', Journal of Applied Corporate Finance, Vol. 17, 2005, pp. 8-23.

Bermig, A. and Frick, B., 'Board size, board composition and firm performance: Empirical evidence from Germany', Working Paper (University of Paderborn, 2010).

Bertrand, M. and Mullainathan, S., 'Are CEOs rewarded for luck? The ones without principals are', Quarterly Journal of Economics, Vol. 116, 2001, pp. 901-932.

Bizjak, J., Lemmon, M. and Nguyen, T., 'Are All CEOs above average? An empirical analysis of compensation peer groups and pay design', Journal of Financial Economics, Vol. 100, 2011, pp. 538-555.

Boehmer, E., Musumeci, J. and Poulsen, A. B., 'Event-study methodology under conditions of event-induced variance', Journal of Financial Economics, Vol. 30, 1991, pp. 253-272.

Boyd, B. K., 'Determinants of US outside director compensation', Corporate Governance: An International Review, Vol. 4, 1996, pp. 202-211.

Boyle, G. and Roberts, H., 'Wolves in the hen-house? The consequences of formal CEO involvement in the executive pay-setting process', Working Paper (University of Canterbury, University of Otago, 2010).

Bresser, R. and Valle Thiele, R., 'Ehemalige Vorstandsvorsitzende als Aufsichtsratschefs: Evidenz zu ihrer Effektivität im Falle des erzwungenen Führungswechsels', Zeitschrift für Betriebswirtschft, Vol. 78, pp. 175-203.

Brown, S. J. and Warner, J. B., 'Using Daily Stock Returns: The Case of Event Studies', Journal of Financial Economics, Vol. 14, 1985, pp. 3-31. 
Bundestag, 'Recommended resolution and report of the legal affairs committee', 6 . committee, parliamentary printing matter, 2009, 16/13433.

Core, J., Holthausen, R. and Larcker, D., 'Corporate governance, chief executive officer compensation and firm performance', Journal of Financial Economics, Vol. 51, 1999, pp. 371-406.

Corrado, C. J., 'A nonparametric test for abnormal security-price performance in event studies', Journal of Financial Economics, Vol. 23, 1989, pp. 385-396.

Da Silva, L. C., Goergen, M. and Renneboog, L., Dividend Policy and Corporate Governance (Oxford University Press, 2004), Chapter 8.

Dittmann, I., Maug, E. and Schneider, C., 'Bankers on the boards of German firms: What they do, what they are worth, and why they are (still) there', Review of Finance, Vol. 14, 2010, pp. 35-71.

Drukker, D. M., 'Testing for serial correlation in linear panel-data models', Stata Journal, Vol. 3, 2003, pp. 168-177.

Elston, A. J. and Goldberg L. G., 'Executive compensation and agency costs in Germany', Journal of Banking and Finance, Vol. 27, 2003, pp. 1391-1410.

Evans, J., Nagarajan, N. and Schloetzer, J., 'CEO turnover and retention light: Retaining former CEOs on the board', Journal of Accounting Research, Vol. 48, 2010, pp. 1015-1047.

Fahlenbrach, R., Low, A, and Stultz, R., 'Why Do Firms Appoint CEOs as Outside Directors?', Journal of Financial Economics, Vol. 97, 2010, pp. 12-32.

Fahlenbrach, R., Minton, B. and Pan, C., 'Former CEO Directors: Lingering CEOs or Valuable Resources?', Review of Financial Studies, Vol. 24, 2011, pp. 3486-3518.

Faulkender, M. and Yang, J., 'Inside the black box: The role and composition of compensation peer groups', Journal of Financial Economics, Vol. 96, 2010, pp. 257-270.

Fiss, P. C., 'Social influence effects and managerial compensation evidence from Germany', Strategic Management Journal, Vol. 27, 2006, pp. 1013-1031.

Franks, J. and Mayer, C., 'Ownership and control of German corporations', Review of Financial Studies, Vol. 14, 2001, pp. 943-977.

Franks, J., Mayer, C., Volpin, P. and Wagner, H., 'The life cycle of family ownership: International evidence', forthcoming in: Review of Financial Studies.

Frydman, C. and Jenter, D., 'CEO compensation', Annual Review of Financial Economics, Vol. 2, 2010, pp. 75-102.

Gabaix, X. and Landier, A., 'Why has CEO pay increased so much?', Quarterly Journal of Economics, Vol. 123, 2008, pp. 49-100. 
Giebe, T. and Gürtler, O., 'Optimal contracts for lenient supervisors', Journal of Economic Behavior \& Organization, Vol. 81, 2012, pp. 403-420.

Gorton, G. and Schmid, F. A., 'Capital, labor, and the firm: A study of German codetermination', Journal of the European Economic Association, Vol. 2, 2004, pp. 863905.

Greene, W. H., Econometric Analysis (Prentice Hall, 2000).

Gregoric, A., Polanec, S. and Siapnicar, S., 'Pay me right: Reference values and executive compensation', European Financial Management, Vol. 16, 2010, pp. 778-804.

Grigoleit, J., 'Kapitalmarktreaktionen auf die Ankündigung des Wechsels von Vorstandsvorsitzenden in den Aufsichtsrat bei deutschen Unternehmen', Zeitschrift für Planung und Unternehmenssteuerung, Vol. 21, 2011, pp. 131-157.

Grigoleit, J., Nippa, M. and Steger, T., 'Ökonomische Konsequenzen der Mitgliedschaft ehemaliger Vorstandsmitglieder im Aufsichtsrat: Eine empirische Analyse', Zeitschrift für betriebswirtschaftliche Forschung, Vol. 63, 2011, pp. 578-608.

Gugler, K. and Yurtoglu, B., 'Corporate governance and dividend policy in Germany', European Economic Review, Vol. 47, 2003, pp. 731-758.

Haid, A. and Yurtoglu, B., 'Ownership structure and executive compensation in Germany', Working Paper (University of Erlangen-Nuremberg, University of Vienna, 2006).

Hallock, K., 'Reciprocally interlocking boards of directors and executive compensation', Journal of Financial and Quantitative Analysis, Vol. 32, 1997, pp. 331-344.

Hartzell, J. and Starks, L., 'Institutional investors and executive compensation', Journal of Finance, Vol. 58, 2003, pp. 2351-2374.

Hill, C. W. and Phan, P., 'CEO tenure as a determinant of CEO pay', Academy of Management Journal, Vol. 34, 1991, pp. 707-717.

Jensen, M. C. and Murphy, K. J., 'Performance pay and top-management incentives', Journal of Political Economy, Vol. 98, 1990, pp. 225-264.

Kaserer, C. and Wagner, N., 'Executive pay, free float, and firm performance: Evidence from Germany', Working Paper (Technical University Munich, Passau University, 2004).

Lawrence, J. and Stapledon, G. P., 'Is board composition important? A study of listed Australian companies', Working Paper (Salomon Smith Barney, University of Melbourne, 1999).

Linn, S. C. and Park, D., 'Outside director compensation policy and the investment opportunity set', Journal of Corporate Finance, Vol. 11, 2005, pp. 680-715. 
Murphy, K. J., 'Corporate performance and managerial remuneration - An empirical analysis', Journal of Accounting and Economics, Vol. 7, 1985, pp.11-42.

Murphy, K. J., 'Executive compensation', in O. Ashenfelter and D. Card, eds, Handbook of Labor Economics, Vol. 3B, (North-Holland, 1999), pp. 2485-2563.

Prendergast, C., 'The provision of incentives in firms', Journal of Economic Literature, Vol. 37, 1999, pp. 7-63.

Prendergast, C. and Topel, R. H., 'Discretion and bias in performance evaluation', European Economic Review, Vol. 37, 1993, pp. 355-365.

Prendergast, C. and Topel, R. H., 'Favoritism in organizations', Journal of Political Economy, Vol. 104, 1996, pp. 958-978.

Ryan, H. E. and Wiggins, R. A., 'The influence of firm- and manager-specific characteristics on the structure of executive compensation', Journal of Corporate Finance, Vol. 7, 2001, pp. 101-123.

Sapp, S. G., 'The impact of corporate governance on executive compensation', European Financial Management, Vol. 14, 2008, pp. 710-746.

Schmid, F., 'Vorstandsbezüge, Aufsichtsratsvergütung und Aktionärsstruktur', $Z f B$ Zeitschrift für Betriebswirtschaft, Vol. 67, 1997, pp. 67-83.

Spiegel (2003), 'Lufthansa - Aufsichtsrat bedient sich', Der Spiegel, Vol. 57, p. 75.

Subrahmanyam, A., 'Social networks and corporate governance', European Financial Management, Vol. 14, 2008, pp. 633-662.

Von Werder, A. and Talaulicar, T., 'Kodex Report 2007: Die Akzeptanz der Empfehlungen und Anregungen des Deutschen Corporate Governance Kodex', Der Betrieb, Vol. 60, 2007, pp. $869-875$.

Westphal, J. D. and Zajac, E. J., 'Who shall govern? CEO/board power, demographic similarity, and new director selection', Administrative Science Quarterly, Vol. 40, 1995, pp. $60-83$.

Wooldridge, J. M., Econometric Analysis of Cross Section and Panel Data (MIT Press, 2002). 
Figure 1

Descriptive statistics on different categories of unforced CEO turnovers (Panel A) and the composition of the supervisory board for each sample year (Panel B)

Figure 1 shows the frequency of unforced CEO turnover events and the number of firm-year observations for the sample period 1998-2007. Based on press releases and additional news coverage, CEO turnovers are categorized into forced and unforced turnovers. Panel A shows the frequency of unforced CEO turnovers for each year of the sample period. Unforced CEO turnovers are further subdivided into the three categories $C E O$ becomes chairman of the board, CEO becomes an ordinary board member and CEO leaves the firm. Panel B depicts different categories of the composition of the supervisory board for each year of the sample period. A firm-year observation is assigned to Former CEO is chairman of the board if the chairman of the supervisory board in the respective year was the CEO of the same company in at least one of the previous years between 1987 and 2006 or in 1985 or in 1982. The variable Former CEO is ordinary board member equals one for the years 1998-2007 if an ordinary member of the supervisory board in the respective year was CEO of the same company in at least one of the previous years between 1987 and 2006 or in 1985 or in 1982. All other firm-year observations are assigned to the category No former CEO on board.

\section{Panel A: CEO turnover}

\# Annual obs.

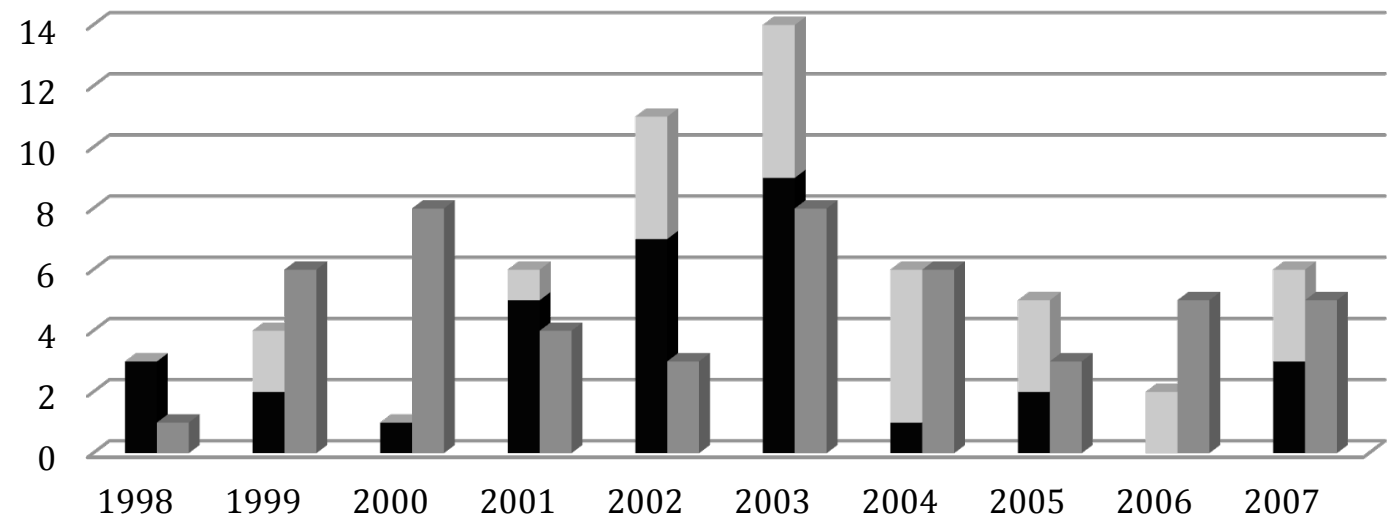

- CEO becomes chairman of the board $\square$ CEO becomes ordinary board member

CEO leaves the firm

\section{Panel B: Firm-year observations}

\# Annual obs.

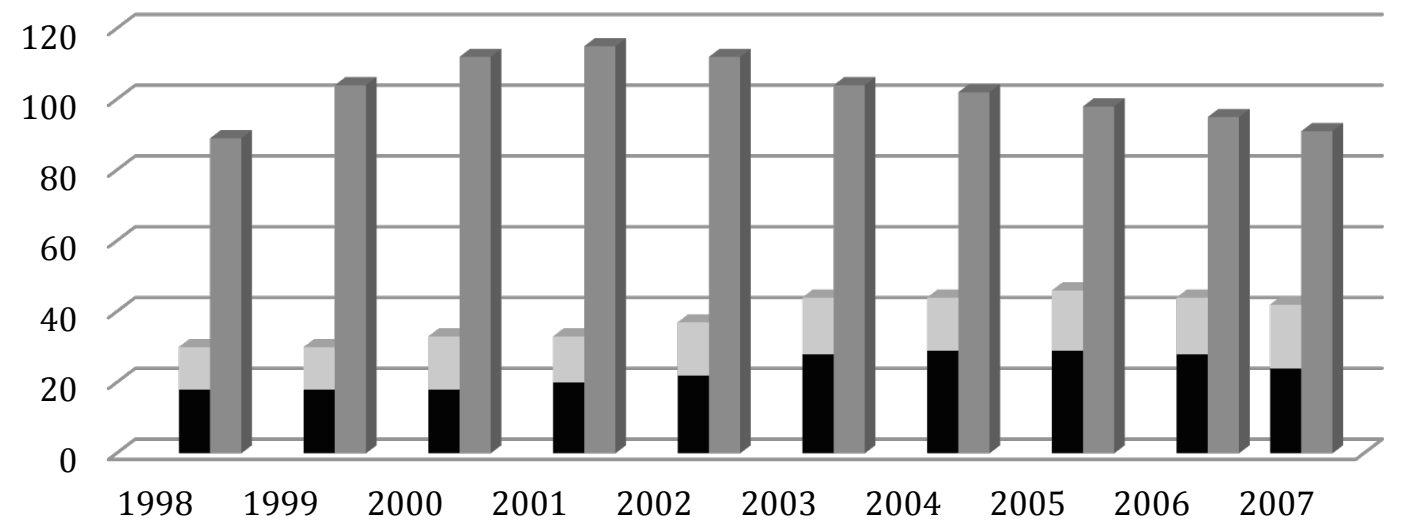

- Former CEO is chairman of the board Former CEO is ordinary board member

No former CEO on board 


\section{Table 1}

\section{Descriptive statistics ordered by year}

The table presents descriptive statistics for all sample firms and for sample firms ordered by dummy variables for the supervisory board composition. Panel A contains information on binary variables. Firms are categorized according to the variables Former CEO is on board, Former CEO is chairman, Former CEO is ordinary board member and No former CEO on board. A firm-year observation is assigned to Former CEO is on board (is chairman/is ordinary board member) if any supervisory board member (the chairman of the supervisory board/an ordinary supervisory board member) in the respective year was the CEO of the same company in at least one of the previous years between 1987 and 2006 or in 1985 or in 1982. All other firm-year observations are assigned to the category No former CEO on board. Panel A contains information on binary ownership variables. For each variable, the number (left column) and percentage (right column) of firms for each category are presented; the percentages are expressed in relation to the total number of firms in each category. The variable largest $50(25)$ corresponds to the number of firms with a largest shareholder holding at least $50 \%(25 \%)$ of the voting equity at the first tier. Firms are classified as widely50(25) if their largest shareholder holds less than $50 \%(25 \%)$ of the voting equity at the first tier. A firm is said to be checked50(25) if the firm has a largest shareholder holding at least $50 \%(25 \%)$ of the voting equity and a second largest shareholder holding at least $5 \%$ of the voting shares at the first tier. Panel B contains the means of cardinal variables for all sample firms and for sample firms ordered by dummy variables for the supervisory board composition. Total assets is measured as the book value of total assets in units of $€ 1,000$; market capitalization is measured as the total market value of equity; executive (supervisory) board size is defined as the number of executive (supervisory) board members; board meetings is defined as the number of supervisory board meetings in the respective fiscal year; CEO tenure is defined as the number of years that the current CEO has served on the executive board (as either CEO or ordinary member); joint tenure is measured as average number of years that the former CEO spent together with the current executive board member on the executive board for firms with a former CEO on the supervisory board and zero otherwise; codetermination is calculated as the number of employee representatives on the supervisory board divided by the total number of supervisory board members; Tobin's $Q$ is computed as the market value of equity plus total assets minus the book value of equity, divided by total assets; share price performance is defined as index-adjusted stock return using the CDAX performance index and measured over the respective fiscal year; $R O A$ is calculated as the ratio of earnings before interest and taxes to total assets; $R O E$ is defined as income before extraordinary items over book value of equity and stake executive (supervisory) board measures the percentage of shares held by the executive (supervisory) board.

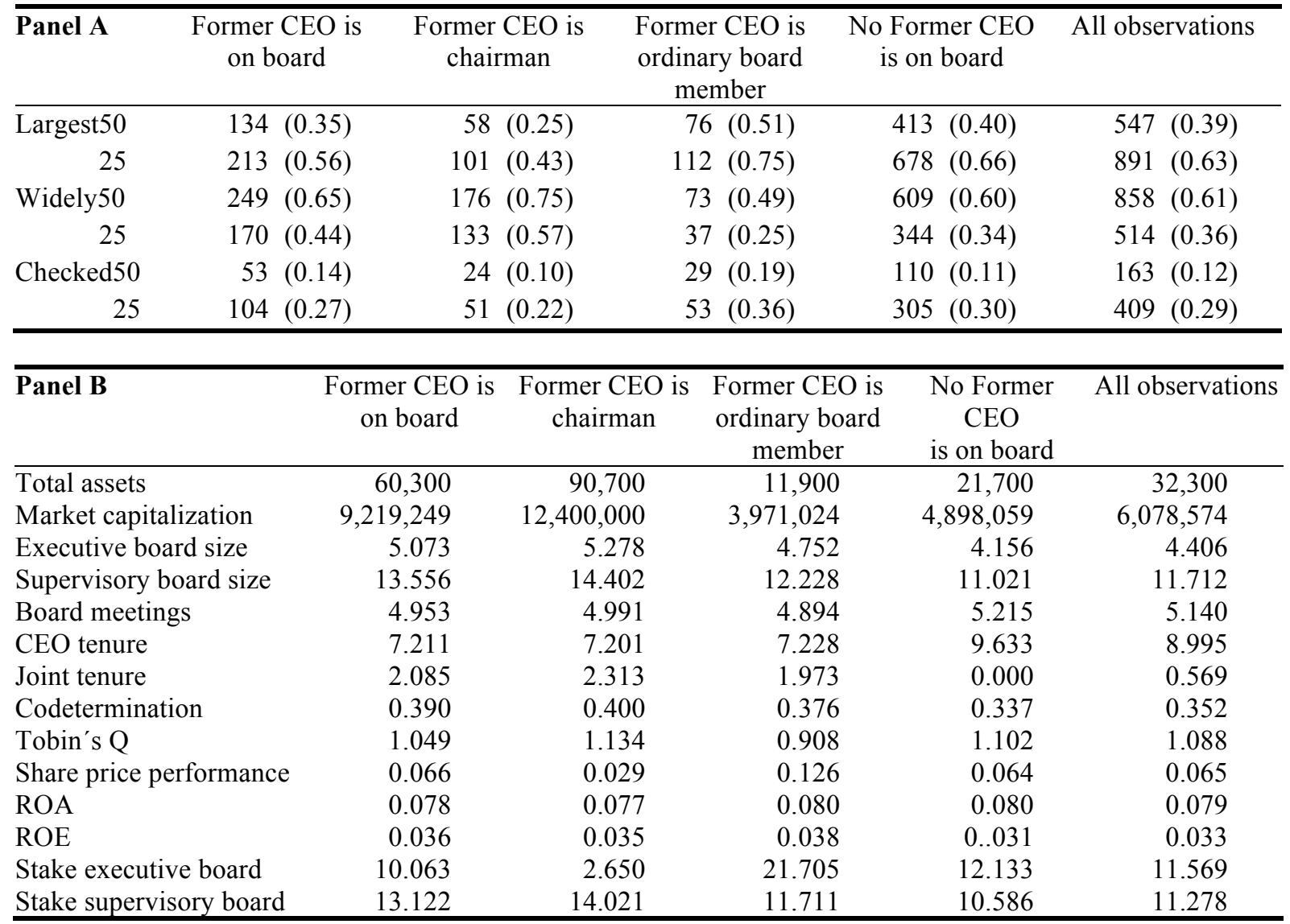


Table 2

\section{Short-run announcement returns}

This table contains cumulative abnormal returns (CARs) of unforced CEO turnover announcements for different event windows (expressed relative to the announcement date $\mathrm{t}=0$ ). Panel A presents results for the full sample (107 observations), while Panel B (C) shows abnormal announcement returns for the subsample of CEOs who leave the firm (become member of the supervisory board) (48 and 59 observations, respectively). T-statistics, the test statistic proposed by Boehmer et al. (1991), and the non-parametric Corrado (1989) test are reported in columns 4, 5, and 6. Asterisks denote statistical significance at the $0.01(* * *), 0.05(* *)$, and $0.10(*)$ levels.

\section{Panel A: All CEO turnover events}

\begin{tabular}{cccccc}
\hline & Pos:Neg & CAR & t-test & $\begin{array}{c}\text { Boehmer } \\
\text { test }\end{array}$ & $\begin{array}{c}\text { Corrado } \\
\text { test }\end{array}$ \\
\hline$[-30 ;+30]$ & $54: 53$ & $0.54 \%$ & 0.28 & 0.06 & 0.34 \\
{$[-10 ;+30]$} & $49: 48$ & $2.13 \%$ & 1.35 & 1.13 & 1.08 \\
{$[-5 ;+5]$} & $58: 49$ & $1.26 \%$ & 1.54 & 0.33 & 0.67 \\
{$[-1 ;+5]$} & $53: 54$ & $-0.33 \%$ & -0.51 & -0.64 & -0.29 \\
{$[0 ;+5]$} & $55: 52$ & $-0.42 \%$ & -0.70 & -0.84 & -0.47 \\
{$[0 ;+3]$} & $45: 62$ & $-0.23 \%$ & -0.47 & -0.65 & -0.02 \\
{$[0 ;+1]$} & $46: 61$ & $-0.36 \%$ & -1.02 & -0.94 & 0.43 \\
{$[0]$} & $60: 47$ & $-0.31 \%$ & -1.24 & -0.80 & 0.84 \\
\hline
\end{tabular}

Panel B: CEO leaves the firm

\begin{tabular}{cccccc}
\hline & Pos:Neg & CAR & t-test & $\begin{array}{c}\text { Boehmer } \\
\text { test }\end{array}$ & $\begin{array}{c}\text { Corrado } \\
\text { test }\end{array}$ \\
\hline$[-30 ;+30]$ & $21: 27$ & $-5.31 \%$ & $-1.81^{*}$ & $-1.94^{*}$ & -1.34 \\
{$[-10 ;+30]$} & $24: 24$ & $-1.30 \%$ & -0.54 & -0.71 & -0.54 \\
{$[-5 ;+5]$} & $23: 25$ & $-0.68 \%$ & -0.54 & -0.56 & -0.54 \\
{$[-1 ;+5]$} & $23: 25$ & $-1.71 \%$ & $-1.72^{*}$ & -0.76 & -0.68 \\
{$[0 ;+5]$} & $24: 24$ & $-1.80 \%$ & $-1.95^{*}$ & -0.97 & -0.97 \\
{$[0 ;+3]$} & $17: 31$ & $-1.14 \%$ & $-1.51^{*}$ & -0.85 & -0.53 \\
{$[0 ;+1]$} & $20: 28$ & $-0.93 \%$ & $-1.74^{*}$ & -0.94 & -0.53 \\
{$[0]$} & $22: 26$ & $-0.87 \%$ & $-2.32^{* *}$ & -1.15 & -0.78 \\
\hline
\end{tabular}

Panel C: CEO becomes supervisory board member

\begin{tabular}{cccccc}
\hline & Pos:Neg & CAR & t-test & $\begin{array}{c}\text { Boehmer } \\
\text { test }\end{array}$ & $\begin{array}{c}\text { Corrado } \\
\text { test }\end{array}$ \\
\hline$[-30 ;+30]$ & $33: 26$ & $5.30 \%$ & $2.07^{* *}$ & $1.71^{*}$ & 1.55 \\
{$[-10 ;+30]$} & $35: 24$ & $4.92 \%$ & $2.35^{* *}$ & $2.49^{* *}$ & $1.88^{*}$ \\
{$[-5 ;+5]$} & $35: 24$ & $2.84 \%$ & $2.62^{* * *}$ & 1.00 & 1.34 \\
{$[-1 ;+5]$} & $30: 29$ & $0.79 \%$ & 0.91 & -0.13 & 0.16 \\
{$[0 ;+5]$} & $31: 28$ & $0.70 \%$ & 0.88 & -0.19 & 0.16 \\
{$[0 ;+3]$} & $28: 31$ & $0.51 \%$ & 0.77 & -0.04 & 0.40 \\
{$[0 ;+1]$} & $26: 33$ & $0.11 \%$ & 0.24 & -0.36 & 1.01 \\
\hline 0$]$ & $38: 21$ & $0.16 \%$ & 0.47 & 0.02 & 1.76 \\
\hline
\end{tabular}




\section{Table 3}

\section{Long-run announcement returns}

This table contains results of long-run event studies following unforced CEO turnover announcements. Abnormal performance is measured for a portfolio of sample firms for up to 12 months following the month of the CEO change. Panels A and B present abnormal returns for a calendar-time approach based on the FamaFrench 3-factor and the Carhart 4-factor model, while Panel C contains buy-and-hold returns based on a marketmodel approach. Factor information for the German market is obtained from the Centre for Financial Research Cologne. The number of observations corresponds to the number of months with a positive number of firms in the portfolio. In each month, firms are included in our portfolio "all turnover events (CEO leaves firm/CEO becomes board member)" if an unforced CEO turnover has occurred within the previous 12 months (and the CEO left the firm or changed to the supervisory board).

\section{Panel A: 3-Factor Model - Calendar-time}

\begin{tabular}{lccccc}
\hline & $\begin{array}{c}\text { Alpha } \\
\text { (t-statistic) }\end{array}$ & $\begin{array}{c}\text { Beta } \\
\text { (t-Statistic) }\end{array}$ & $\begin{array}{c}\text { SMB } \\
\text { (t-statistic) }\end{array}$ & $\begin{array}{c}\text { HML } \\
\text { (t-Statistic) }\end{array}$ & $\begin{array}{c}\text { Number of } \\
\text { observations }\end{array}$ \\
\hline All turnover events & -0.006 & 1.193 & 0.618 & 0.405 & 137 \\
CEO leaves firm & $(-0.12)$ & $(13.88)$ & $(4.89)$ & $(3.46)$ & \\
& -0.007 & 0.871 & 0.314 & 0.357 & 118 \\
CEO becomes board member & $(-1.28)$ & $(7.95)$ & $(2.18)$ & $(2.81)$ & \\
& 0.006 & 1.252 & 0.601 & 0.299 & 137 \\
\hline
\end{tabular}

Panel B: 4-Factor Model - Calendar-time

\begin{tabular}{lcccccc}
\hline & $\begin{array}{c}\text { Alpha } \\
\text { (t-statistic) }\end{array}$ & $\begin{array}{c}\text { Beta } \\
\text { (t-Statistic) }\end{array}$ & $\begin{array}{c}\text { SMB } \\
\text { (t-statistic) }\end{array}$ & $\begin{array}{c}\text { HML } \\
\text { (t-Statistic) }\end{array}$ & $\begin{array}{c}\text { MOM } \\
\text { (t-statistic) }\end{array}$ & $\begin{array}{c}\text { Number of } \\
\text { observations }\end{array}$ \\
\hline All turnover events & 0.003 & 1.072 & 0.519 & 0.435 & -0.228 & 137 \\
& $(0.51)$ & $(10.84)$ & $(3.96)$ & $(3.76)$ & $(-2.37)$ & \\
CEO leaves firm & -0.006 & 0.832 & 0.281 & 0.369 & -0.080 & 118 \\
& $(-1.02)$ & $(6.76)$ & $(1.86)$ & $(2.88)$ & $(-0.71)$ & \\
CEO becomes & 0.009 & 1.137 & 0.507 & 0.327 & -0.215 & 137 \\
board member & $(1.50)$ & $(10.17)$ & $(3.43)$ & $(2.50)$ & $(-1.98)$ & \\
\hline
\end{tabular}

Panel C: Buy-and-Hold Returns

\begin{tabular}{cccc}
\hline & $\begin{array}{c}\text { BHAR (t-statistic) } \\
\text { All turnover events }\end{array}$ & $\begin{array}{c}\text { BHAR (t-statistic) } \\
\text { CEO leaves firm }\end{array}$ & $\begin{array}{c}\text { BHAR (t-statistic) } \\
\text { CEO becomes board } \\
\text { member }\end{array}$ \\
\hline \multirow{2}{*}{2 months } & $-1.51 \%$ & $-4.22 \%$ & $0.74 \%$ \\
& $(-0.85)$ & $(1.82)$ & $(0.28)$ \\
4 months & $1.34 \%$ & $-2.67 \%$ & $4.67 \%$ \\
& $(0.48)$ & $(-0.66)$ & $(1.22)$ \\
\multirow{2}{*}{6 months } & $-0.15 \%$ & $-4.05 \%$ & $3.10 \%$ \\
& $(-0.05)$ & $(-0.88)$ & $(0.75)$ \\
& $0.81 \%$ & $-4.93 \%$ & $(1.04)$ \\
10 months & $(0.22)$ & $-2.33 \%$ & $9.22 \%$ \\
& $3.98 \%$ & $(-0.40)$ & $(1.22)$ \\
& $(0.81)$ & $2.87 \%$ & $10.36 \%$ \\
\end{tabular}


Table 4

\section{Operating performance}

This table contains the results of a difference-in-differences analysis of operating performance around CEO turnover events. We compare firms in which a former CEO changes to the supervisory board to firms in which a retiring CEO leaves the firm. Return on assets (ROA) is defined as income before extraordinary items plus interest expenses over total assets. Return on equity is defined as income before extraordinary items over book value of equity. Excess ROA and ROE are measured relative to a control group of firms matched on industry, size and prior performance. See Fahlenbrach et al. (2011) for details regarding the construction of our measures of excess operating performance. The difference-in-differences analysis compares average (excess) ROA and ROE under the old CEO (average of years t-2 and t-1) to average (excess) performance under the new CEO (years $\mathrm{t}+1$ and $\mathrm{t}+1$, relative to the turnover year $(\mathrm{t}=0)$ ). The superscript $*$ denotes statistical significance at the $10 \%$ level.

\section{Panel A: Excess performance}

\begin{tabular}{lccc}
\hline & $\begin{array}{c}\text { Former CEO changes to } \\
\text { the supervisory board }\end{array}$ & $\begin{array}{c}\text { Former CEO does not } \\
\text { change to the supervisory } \\
\text { board }\end{array}$ & Difference \\
\hline ROA & $(\mathrm{N}=50)$ & $(\mathrm{N}=35)$ & -0.003 \\
\hline $\begin{array}{l}\text { Average excess ROA } \\
(\mathrm{t}-2, \mathrm{t}-1)\end{array}$ & 0.013 & 0.017 & {$[-0.006]$} \\
$\begin{array}{l}\text { Average excess ROA } \\
(\mathrm{t}+1, \mathrm{t}+2)\end{array}$ & 0.020 & 0.029 & -0.008 \\
Change in excess ROA & 0.007 & 0.012 & {$[-0.014]$} \\
& {$[0.009]$} & {$[0.014]$} & -0.005 \\
& & & {$[-0.016]$} \\
\hline ROE & $(\mathrm{N}=48)$ & $(\mathrm{N}=33)$ & -0.009 \\
\hline $\begin{array}{l}\text { Average excess ROE } \\
(\mathrm{t}-2, \mathrm{t}-1)\end{array}$ & 0.008 & 0.017 & {$[-0.008]$} \\
$\begin{array}{l}\text { Average excess ROE } \\
(\mathrm{t}+1, \mathrm{t}+2)\end{array}$ & 0.034 & -0.003 & 0.037 \\
Change in excess ROE & 0.026 & -0.020 & {$[0.095]$} \\
& {$[0.078]$} & {$[-0.021]$} & 0.046 \\
\hline
\end{tabular}

Panel B: Raw performance

\begin{tabular}{lccc}
\hline & $\begin{array}{c}\text { Former CEO changes to } \\
\text { the supervisory board }\end{array}$ & $\begin{array}{c}\text { Former CEO does not } \\
\text { change to the supervisory } \\
\text { board }\end{array}$ & Difference \\
\hline ROA & $(\mathrm{N}=52)$ & $(\mathrm{N}=35)$ & 0.003 \\
\hline $\begin{array}{l}\text { Average ROA } \\
(\mathrm{t}-2, \mathrm{t}-1)\end{array}$ & 0.077 & 0.074 & {$[0.015]$} \\
$\begin{array}{l}\text { Average ROA } \\
(\mathrm{t}+1, \mathrm{t}+2)\end{array}$ & 0.077 & 0.063 & 0.014 \\
Change in ROA & -0.000 & -0.011 & $0.014]$ \\
& {$[-0.010]$} & {$[-0.011]$} & 0.011 \\
& & & {$[0.014]$} \\
\hline ROE & $(\mathrm{N}=52)$ & $(\mathrm{N}=35)$ & -0.009 \\
\hline $\begin{array}{l}\text { Average ROE } \\
(\mathrm{t}-2, \mathrm{t}-1)\end{array}$ & 0.033 & 0.041 & {$[-0.013]$} \\
$\begin{array}{l}\text { Average ROE } \\
(\mathrm{t}+1, \mathrm{t}+2)\end{array}$ & 0.034 & 0.011 & 0.023 \\
Change in ROE & 0.001 & $-0.030^{*}$ & {$[0.023]$} \\
& {$[0.009]$} & {$[-0.016]$} & $0.032^{*}$ \\
\hline
\end{tabular}




\section{Table 5}

Descriptive statistics for director and executive compensation ordered by year (Panel A) and by dummy variable for different categories of the composition of the supervisory board

(Panel B)

Panel A presents descriptive statistics for director and executive compensation. For each variable, it shows the mean, median, standard deviation, and number of observations for selected years from 1998 to 2007 and for the entire sample period. The variable director compensation is measured as the total compensation of the supervisory board in Euros divided by the number of supervisory board members in the respective year. The variable executive compensation is measured as the total compensation of the executive board in Euros divided by the number of executive board members in the respective year. A firm-year observation is assigned to Former CEO is on board (is chairman/is ordinary board member) if any supervisory board member (the chairman of the supervisory board/an ordinary supervisory board member) in the respective year was the CEO of the same company in at least one of the previous years between 1987 and 2006 or in 1985 or in 1982. All other firm-year observations are assigned to the category No former CEO on board. Panel B contains the mean, median, standard deviation and number of observations ordered by dummy variables for the supervisory board composition. Values in parentheses in the first three columns correspond to p- and z-values for tests of statistical difference in means and median across firm-years assigned to the categories Former CEO is on board (is chairman/is ordinary board member) and the category No former CEO on board. The superscripts *, **, and *** denote significance differences at the $10 \%, 5 \%$, and $1 \%$ levels, respectively.

\begin{tabular}{lcccccc}
\hline Panel A & $\mathbf{1 9 9 9}$ & $\mathbf{2 0 0 1}$ & $\mathbf{2 0 0 3}$ & $\mathbf{2 0 0 5}$ & $\mathbf{2 0 0 7}$ & $\mathbf{1 9 9 8 - 2 0 0 7}$ \\
\hline Director compensation & & & & & & \\
Mean & 32,404 & 42,546 & 40,085 & 48,184 & 60,437 & 43,853 \\
Median & 24,010 & 25,250 & 27,157 & 36,690 & 43,333 & 30,000 \\
Std. dev. & 27,686 & 67,578 & 34,854 & 38,748 & 49,675 & 48,899 \\
Obs. & 126 & 146 & 145 & 140 & 131 & 1,371
\end{tabular}

Executive compensation

\begin{tabular}{|c|c|c|c|c|c|c|}
\hline Mean & 649,684 & 770,631 & 902,040 & $1,136,793$ & $1,449,404$ & 944,344 \\
\hline Median & 517,833 & 580,000 & 656,000 & 811,500 & $1,140,925$ & 656,000 \\
\hline Std. dev. & 580,240 & 720,443 & 839,870 & $1,161,696$ & $1,165,000$ & 907,752 \\
\hline Obs. & 122 & 145 & 145 & 140 & 131 & 1,359 \\
\hline Panel B & \multicolumn{2}{|c|}{$\begin{array}{c}\text { Former CEO is } \\
\text { on board }\end{array}$} & $\begin{array}{c}\text { Former CEO is } \\
\text { chairman }\end{array}$ & \multicolumn{2}{|c|}{$\begin{array}{c}\text { Former CEO is } \\
\text { ordinary board } \\
\text { member }\end{array}$} & $\begin{array}{l}\text { No Former } \\
\text { CEO } \\
\text { is on board }\end{array}$ \\
\hline \multicolumn{7}{|c|}{ Director compensation } \\
\hline Mean & \multicolumn{2}{|c|}{$\begin{array}{l}59,037 * * * \\
(7.24)\end{array}$} & $\begin{array}{l}65,227 * * * \\
(7.61)\end{array}$ & \multicolumn{2}{|c|}{$\begin{array}{l}49,374 * * * \\
(2.77)\end{array}$} & 38,051 \\
\hline Median & \multicolumn{2}{|c|}{$\begin{array}{l}46,667 * * * \\
(8.65)\end{array}$} & $\begin{array}{l}50,000 * * * \\
(8.81)\end{array}$ & \multicolumn{2}{|c|}{$\begin{array}{l}37,083 * * * \\
(3.79)\end{array}$} & 25,841 \\
\hline Std. dev. & \multicolumn{2}{|c|}{49,487} & 54,772 & \multicolumn{2}{|c|}{38,052} & 47,430 \\
\hline Obs. & \multicolumn{2}{|c|}{379} & 231 & \multicolumn{2}{|c|}{148} & 992 \\
\hline \multicolumn{7}{|c|}{ Executive compensation } \\
\hline Mean & \multicolumn{2}{|c|}{$\begin{array}{c}1202,105 * * * \\
(-6.61)\end{array}$} & $\begin{array}{c}1366,321 * * * \\
(-8.12)\end{array}$ & \multicolumn{2}{|c|}{$\begin{array}{l}945,795 \\
(-1 . .49)\end{array}$} & 844,659 \\
\hline Median & \multicolumn{2}{|c|}{$\begin{array}{l}763,600 * * * \\
(5.65)\end{array}$} & $\begin{array}{c}907,667 * * * \\
(6.59)\end{array}$ & \multicolumn{2}{|c|}{$\begin{array}{c}648,071 \\
(1.41)\end{array}$} & 619,833 \\
\hline Std. dev. & \multicolumn{2}{|c|}{1205,028} & 1313,252 & \multicolumn{2}{|c|}{962,825} & 739,380 \\
\hline Obs. & \multicolumn{2}{|c|}{379} & 231 & \multicolumn{2}{|c|}{148} & 980 \\
\hline
\end{tabular}




\section{Table 6A}

\section{Determinants of executive compensation}

The table shows the results of fixed effects regressions with per capita executive compensation as the dependent variable. The variable executive compensation is measured as the total compensation of the executive board in units of $€ 1,000$ divided by the number of executive board members in the respective year. The first column shows the independent variables. The variable Former CEO is on board (is chairman/is ordinary board member) is equal to one, if any supervisory board member (the chairman of the supervisory board/an ordinary supervisory board member) in the respective year was the CEO of the same company in at least one of the previous years between 1987 and 2006 or in 1985 or in 1982 and zero otherwise. Ln(number of executives) is defined as the natural logarithm of the number of executive board members. CEO tenure is defined as the number of years that the current CEO has served on the executive board (as either CEO or ordinary member). The variable stake executive (supervisory) board measures the percentage of shares held by members of the executive (supervisory) board. The variable largest shareholder holds $>50 \%$ is a dummy that is set to one for all firms with a largest shareholder holding at least $50 \%$ of the voting equity. A firm is said to be checked if the second largest shareholder holds at least $5 \%$ of the voting shares at the first tier. The variable codetermination is defined as the number of employee representatives divided by the number of supervisory board members in the respective year; $\ln$ (market capitalization) is defined as the natural logarithm of the total market value of equity; share price performance is computed as the annual change in the share price from the previous year, index-adjusted using the CDAX performance index; and Tobin's $Q$ is defined as the market value of equity plus total assets minus the book value of equity, divided by total assets. The coefficient for constant is the average value of the fixed effects as obtained from Stata 11. Each cell shows the estimated coefficient and t-value (in parentheses). The superscripts $* * *$, and $* * *$ denote significance at the $10 \%, 5 \%$, and $1 \%$ levels, respectively.

\begin{tabular}{|c|c|c|c|c|}
\hline & $(1)$ & $(2)$ & (3) & (4) \\
\hline Constant & $\begin{array}{c}-2433.39 * * * \\
(-5.24)\end{array}$ & $\begin{array}{c}-2437.19 * * * \\
(-5.22)\end{array}$ & $\begin{array}{c}-2587.68 * * * \\
(-5.55)\end{array}$ & $\begin{array}{c}-2595.44 * * * \\
(-5.55)\end{array}$ \\
\hline Former CEO on board & $\begin{array}{l}124.63^{* *} \\
(2.12)\end{array}$ & & $\begin{array}{l}145.42 * * \\
(2.50)\end{array}$ & \\
\hline Former CEO is chairman & & $\begin{array}{c}126 . .96 * * \\
(1.97)\end{array}$ & & $\begin{array}{c}150.99 * * \\
(2.35)\end{array}$ \\
\hline $\begin{array}{l}\text { Former CEO is ordinary } \\
\text { board member }\end{array}$ & & $\begin{array}{r}119.48 \\
(1.45)\end{array}$ & & $\begin{array}{r}134.27^{*} \\
(1.68)\end{array}$ \\
\hline Ln (number of executives) & $\begin{array}{l}-479.67 * * * \\
(-7.29)\end{array}$ & $\begin{array}{l}-479.80 * * * \\
(-7.29)\end{array}$ & $\begin{array}{c}-507.91 * * * \\
(-7.69)\end{array}$ & $\begin{array}{l}-508.11 * * * \\
(-7.69)\end{array}$ \\
\hline CEO tenure & $\begin{array}{r}5.81^{*} \\
(1.83)\end{array}$ & $\begin{array}{r}5.83^{*} \\
(1.84)\end{array}$ & $\begin{array}{l}6.55^{* *} \\
(2.07)\end{array}$ & $\begin{array}{l}6.58^{* *} \\
(2.07)\end{array}$ \\
\hline Stake executive board & $\begin{array}{c}1.37 \\
(0.85)\end{array}$ & $\begin{array}{c}1.37 \\
(0.85)\end{array}$ & $\begin{array}{c}1.81 \\
(1.13)\end{array}$ & $\begin{array}{r}1.815 \\
(1.13)\end{array}$ \\
\hline Stake supervisory board & $\begin{array}{l}4.22 * * * \\
(3.38)\end{array}$ & $\begin{array}{l}4.21 * * * \\
(3.38)\end{array}$ & $\begin{array}{l}4.29 * * * \\
(3.45)\end{array}$ & $\begin{array}{l}4.287 * * * \\
(3.44)\end{array}$ \\
\hline Largest shareholder $>50 \%$ & $\begin{array}{l}-80.33 \\
(-1.46)\end{array}$ & $\begin{array}{l}-80.39 \\
(-1.46)\end{array}$ & $\begin{array}{l}-88.62 \\
(-1.61)\end{array}$ & $\begin{array}{l}-88.76 \\
(-1.61)\end{array}$ \\
\hline Checked & $\begin{array}{l}133.74 * * \\
(2.26)\end{array}$ & $\begin{array}{c}133.66^{* *} \\
(2.26)\end{array}$ & $\begin{array}{c}137.23 * * \\
(2.31)\end{array}$ & $\begin{array}{l}137.13^{* *} \\
(2.30)\end{array}$ \\
\hline Codetermination & $\begin{array}{l}-17.50 \\
(-0.08)\end{array}$ & $\begin{array}{l}-18.23 \\
(-0.08)\end{array}$ & $\begin{array}{l}-94.80 \\
(-0.42)\end{array}$ & $\begin{array}{l}-96.39 \\
(-0.43)\end{array}$ \\
\hline Ln(market capitalization) & $\begin{array}{l}263.74 * * * \\
(7.51)\end{array}$ & $\begin{array}{l}264.05 * * * \\
(7.48)\end{array}$ & $\begin{array}{l}280.47 * * * \\
(8.14)\end{array}$ & $\begin{array}{l}281.10^{* * * *} \\
(8.13)\end{array}$ \\
\hline ROA & $\begin{array}{l}541.48^{* *} \\
(2.05)\end{array}$ & $\begin{array}{l}541.33 * * \\
(2.05)\end{array}$ & & \\
\hline Share price performance & & & $\begin{array}{l}-12.89 \\
(-0.43)\end{array}$ & $\begin{array}{l}-12.73 \\
(-0.42)\end{array}$ \\
\hline Tobin's Q & $\begin{array}{c}-48.14 * \\
(-1.93)\end{array}$ & $\begin{array}{c}-48.18 * \\
(-1.93)\end{array}$ & $\begin{array}{c}-50.96^{*} \\
(-1.93)\end{array}$ & $\begin{array}{c}-51.05^{*} \\
(-1.93)\end{array}$ \\
\hline Year dummies & yes & yes & yes & yes \\
\hline$\overline{\mathrm{R}^{2} \text { within }}$ & 0.332 & 0.332 & 0.336 & 0.336 \\
\hline $\mathrm{R}^{2}$ between & 0.516 & 0.516 & 0.511 & 0.512 \\
\hline $\mathrm{R}^{2}$ overall & 0.444 & 0.444 & 0.444 & 0.445 \\
\hline $\mathrm{N}$ & 1287 & 1287 & 1281 & 1281 \\
\hline
\end{tabular}




\section{Table 6B}

\section{Determinants of executive compensation}

The table shows the results of fixed effects regressions with per capita executive compensation as the dependent variable. The variable executive compensation is measured as the total compensation of the executive board in units of $€ 1,000$ divided by the number of executive board members in the respective year. The first column shows the independent variables. The variable Former CEO is on board (is chairman/is ordinary board member) is equal to one, if any supervisory board member (the chairman of the supervisory board/an ordinary supervisory board member) in the respective year was the CEO of the same company in at least one of the previous years between 1987 and 2006 or in 1985 or in 1982 and zero otherwise. These dummy variables are interacted with joint tenure, which measures the average number of years that the former CEO spent together with the current executive board member on the executive board. Ln(number of executives) is defined as the natural logarithm of the number of executive board members. CEO tenure is defined as the number of years that the current CEO has served on the executive board (as either CEO or ordinary member). The variable stake executive (supervisory) board measures the percentage of shares held by members of the executive (supervisory) board. The variable largest shareholder holds $>50 \%$ is a dummy that is set to one for all firms with a largest shareholder holding at least $50 \%$ of the voting equity. A firm is said to be checked if the second largest shareholder holds at least $5 \%$ of the voting shares at the first tier. The variable codetermination is defined as the number of employee representatives divided by the number of supervisory board members in the respective year; $\ln ($ market capitalization) is defined as the natural logarithm of the total market value of equity; share price performance is computed as the annual change in the share price from the previous year, index-adjusted using the CDAX performance index; and Tobin's $Q$ is defined as the market value of equity plus total assets minus the book value of equity, divided by total assets. The coefficient for constant is the average value of the fixed effects as obtained from Stata 11. Each cell shows the estimated coefficient and t-value (in parentheses). The superscripts *, **, and *** denote significance at the $10 \%, 5 \%$, and $1 \%$ levels, respectively.

\begin{tabular}{|c|c|c|c|c|}
\hline & $(5)$ & $(6)$ & $(7)$ & $(8)$ \\
\hline Constant & $\begin{array}{c}-2436.82 * * * \\
(5.25)\end{array}$ & $\begin{array}{c}-2441.55 * * * \\
(-5.25)\end{array}$ & $\begin{array}{c}-2588.84 * * * \\
(-5.56)\end{array}$ & $\begin{array}{c}-2591.60 * * * \\
(-5.56)\end{array}$ \\
\hline $\begin{array}{l}\text { Former CEO on board* } \\
\text { joint tenure }\end{array}$ & $\begin{array}{l}39.23 * * \\
(2.48)\end{array}$ & & $\begin{array}{l}42.22 * * * \\
(2.76)\end{array}$ & \\
\hline $\begin{array}{l}\text { Former CEO is chairman* } \\
\text { joint tenure }\end{array}$ & & $\begin{array}{l}39.93 * * \\
(2.36)\end{array}$ & & $\begin{array}{l}44.92 * * * \\
(2.69)\end{array}$ \\
\hline $\begin{array}{l}\text { Former CEO is ordinary } \\
\text { board member*joint tenure }\end{array}$ & & $\begin{array}{l}25.99 \\
(0.97)\end{array}$ & & $\begin{array}{l}25.82 \\
(1.04)\end{array}$ \\
\hline Ln (number of executives) & $\begin{array}{l}-473.62 * * * \\
\quad(-7.22)\end{array}$ & $\begin{array}{l}-472.85 * * * \\
(-7.20)\end{array}$ & $\begin{array}{l}-500.34 * * * \\
\quad(-7.59)\end{array}$ & $\begin{array}{l}-498.92 * * * \\
(-7.57)\end{array}$ \\
\hline CEO tenure & $\begin{array}{r}5.22 * \\
(1.71)\end{array}$ & $\begin{array}{l}5.10^{*} \\
(1.67)\end{array}$ & $\begin{array}{l}5.73^{*} \\
(1.88)\end{array}$ & $\begin{array}{r}5.57^{*} \\
(1.83)\end{array}$ \\
\hline Stake executive board & $\begin{array}{l}1.35 \\
(0.85)\end{array}$ & $\begin{array}{l}1.40 \\
(0.87)\end{array}$ & $\begin{array}{c}1.77 \\
(1.10)\end{array}$ & $\begin{array}{c}1.83 \\
(1.14)\end{array}$ \\
\hline Stake supervisory board & $\begin{array}{l}4.32 * * * \\
(3.48)\end{array}$ & $\begin{array}{l}4.33 * * * \\
(3.48)\end{array}$ & $\begin{array}{l}4.42 * * * \\
(3.57)\end{array}$ & $\begin{array}{l}4.42 * * * \\
(3.56)\end{array}$ \\
\hline Largest shareholder $>50 \%$ & $\begin{array}{l}-77.85 \\
(-1.42)\end{array}$ & $\begin{array}{l}-78.17 \\
(-1.42)\end{array}$ & $\begin{array}{l}-86.87 \\
(-1.58)\end{array}$ & $\begin{array}{l}-87.27 \\
(-1.58)\end{array}$ \\
\hline Checked & $\begin{array}{l}132.70 * * \\
(2.25)\end{array}$ & $\begin{array}{l}128.73 * * \\
(2.17)\end{array}$ & $\begin{array}{c}135.31^{* *} \\
(2.28)\end{array}$ & $\begin{array}{l}130.29 * * \\
(2.19)\end{array}$ \\
\hline Codetermination & $\begin{array}{l}-39.41 \\
(-0.18)\end{array}$ & $\begin{array}{l}-49.11 \\
(-0.23)\end{array}$ & $\begin{array}{r}-119.81 \\
(-0.53)\end{array}$ & $\begin{array}{r}-133.19 \\
(-0.59)\end{array}$ \\
\hline Ln(market capitalization) & $\begin{array}{l}264.86^{* * * *} \\
(7.55)\end{array}$ & $\begin{array}{l}265.61 * * * \\
(7.56)\end{array}$ & $\begin{array}{l}281.92 * * * \\
(8.19)\end{array}$ & $\begin{array}{l}282.53 * * * \\
(8.20)\end{array}$ \\
\hline ROA & $\begin{array}{l}550.24 * * \\
(2.09)\end{array}$ & $\begin{array}{l}545.74 * * \\
(2.07)\end{array}$ & & \\
\hline Share price performance & & & $\begin{array}{l}-10.15 \\
(-0.34)\end{array}$ & $\begin{array}{l}-9.65 \\
(-0 . .32)\end{array}$ \\
\hline Tobin's Q & $\begin{array}{l}-50.73 * * \\
(-2.04)\end{array}$ & $\begin{array}{l}-50.79 * * \\
(-2.04)\end{array}$ & $\begin{array}{l}-53.91 * * \\
(-2.04)\end{array}$ & $\begin{array}{l}-54.20 * * \\
(-2.05)\end{array}$ \\
\hline Year dummies & yes & yes & yes & yes \\
\hline $\mathrm{R}^{2}$ within & 0.331 & 0.333 & 0.337 & 0.337 \\
\hline $\mathrm{R}^{2}$ between & 0.535 & 0.535 & 0.535 & 0.535 \\
\hline $\mathrm{R}^{2}$ overall & 0.457 & 0.457 & 0.460 & 0.460 \\
\hline $\mathrm{N}$ & 1287 & 1287 & 1281 & 1281 \\
\hline
\end{tabular}




\section{Table 7}

\section{Director and executive compensation: Difference in differences}

This table shows the levels and changes of director and executive compensation around unforced CEO turnovers using the difference-in-differences methodology. Based on press releases and additional news coverage, CEO turnovers are categorized into forced and unforced turnovers. Before corresponds to the average per capita executive (director) compensation (in $€$ ) in the last two years of the CEO under consideration on the executive board, whereas after refers to the average per capita executive (director) compensation (in $€$ ) in the five years following the CEO turnover. All firms whose former CEO transfers to the supervisory board (becomes the chairman of the supervisory board/becomes an ordinary supervisory board member) are defined as the treatment group, whereas all firms whose retiring CEO leaves the firm are defined as the control group. The third row shows the difference in director or executive compensation before and after CEO turnover. The third column gives the differences between the treatment and control groups before and after CEO turnover and the difference between the differences in executive or director compensation before and after CEO turnover for the treatment and control groups. The mean is reported for each table cell. For the third row and third column, t-tests are used to test if the mean difference is significantly different from zero. The superscripts *, **, and *** denote significance at the $10 \%, 5 \%$, and $1 \%$ levels, respectively. Panel A (B) contains the analysis for executive (director) compensation.

\begin{tabular}{lccc}
\hline $\begin{array}{l}\text { Panel A: } \\
\text { Executive compensation }\end{array}$ & $\begin{array}{c}\text { Treatment group } \\
(1)\end{array}$ & $\begin{array}{c}\text { Control group } \\
(2)\end{array}$ & $\begin{array}{c}\text { Difference } \\
(3)\end{array}$ \\
\hline CEO changes to the board & & & \\
Before & 1020,818 & 707,939 & 312,879 \\
After & 1568,073 & 990,482 & $577,591 * *$ \\
Difference & $547,255^{* * *}$ & $282,543 * * *$ & 264,711 \\
CEO becomes chairman & & & $503,269 *$ \\
Before & 1211,208 & 707,939 & $770,390 *$ \\
After & 1760,873 & 990,482 & 267,122 \\
Difference & $549,665 * * *$ & $282,543 * * *$ & 27,294 \\
CEO becomes ordinary board member & & & 288,391 \\
Before & 735,233 & 707,939 & 261,097 \\
After & 1278,873 & 990,482 & $282,543 * * *$ \\
Difference & $543,640^{* * *}$ & & \\
\hline
\end{tabular}

Panel B: $\quad$ Treatment group $\quad$ Control group $\quad$ Difference

\section{Director compensation}

(1)

(2)

(3)

CEO changes to the board

Before

After

Difference

CEO becomes chairman

Before

After

Difference

CEO becomes ordinary board member

Before

After

Difference

\section{3,104}

78,518

$25,414 * * *$

57,172

81,624

$24,452 * * *$

46,643

73,584

$26,941 * * *$
28,179

$24,924 * * *$

44,409

$34,109 * * *$

$16,229 * * *$

9,185

$28,992 * * *$

$37,215 * * *$

8,223 


\section{Table 8}

\section{Determinants of executive compensation: Difference in differences}

This table shows the results of fixed effects regressions using the difference-in-differences methodology with per capita executive compensation as the dependent variable and the last two years prior to and the first five year following unforced CEO turnovers as observations. The variable executive compensation is measured as the total compensation of the executive board in units of $€ 1,000$ divided by the number of executive board members. The first column shows the independent variables. The variable post is equal to one for observations in the two-year period prior to the CEO turnover, and zero otherwise. Post*treatment measures the difference between the differences of executive compensation before and after CEO turnover for the treatment and control groups. The control group consists of all firms whose former CEO leaves the firm. For columns $1(2 / 3)$ the treatment group consists of all firms whose former CEO transfers to the supervisory board (becomes the chairman of the supervisory board/becomes an ordinary supervisory board member). Ln(number of executives) is defined as the natural logarithm of the number of executive board members. CEO tenure is defined as the number of years that the current CEO has served on the executive board (as either CEO or ordinary member). The variable largest shareholder holds $>50 \%$ is a dummy that is set to one for all firms with a largest shareholder holding at least $50 \%$ of the voting equity. A firm is said to be checked if the second largest shareholder holds at least $5 \%$ of the voting shares at the first tier. The variable codetermination is defined as the number of employee representatives divided by the number of supervisory board members in the respective year; the variable stake executive (supervisory) board measures the percentage of shares held by members of the executive (supervisory) board; In(market capitalization) is defined as the natural logarithm of the total market value of equity; share price performance is computed as the annual change in the share price from the previous year, index-adjusted using the CDAX performance index; and Tobin's $Q$ is defined as the market value of equity plus total assets minus the book value of equity, divided by total assets. The coefficient for constant is the average value of the fixed effects as obtained from Stata 11. Each cell shows the estimated coefficient and t-value (in parentheses). The superscripts $* * *$, and $* * *$ denote significance at the $10 \%, 5 \%$, and $1 \%$ levels, respectively.

\begin{tabular}{|c|c|c|c|}
\hline & $\begin{array}{l}\text { Former CEO changes to } \\
\text { the supervisory board }\end{array}$ & $\begin{array}{l}\text { Former CEO becomes } \\
\text { chairman of the board }\end{array}$ & $\begin{array}{l}\text { Former CEO becomes } \\
\text { ordinary board member }\end{array}$ \\
\hline & $(1)$ & $(2)$ & $(3)$ \\
\hline Constant & $\begin{array}{r}-276.88 \\
(-0.16)\end{array}$ & $\begin{array}{r}-2632.88 \\
(-1.17)\end{array}$ & $\begin{array}{r}884.83 \\
(0.58)\end{array}$ \\
\hline Post & $\begin{array}{l}-20.61 \\
(-0.12)\end{array}$ & $\begin{array}{c}5.45 \\
(0.03)\end{array}$ & $\begin{array}{r}-167.88 \\
(-0.75)\end{array}$ \\
\hline Post*treatment & $\begin{array}{r}217.53 \\
(1.47)\end{array}$ & $\begin{array}{c}300.99 * * \\
(2.09)\end{array}$ & $\begin{array}{r}216.12 \\
(1.06)\end{array}$ \\
\hline Ln(number of executives) & $\begin{array}{l}-625.85 * * * \\
(-3.99)\end{array}$ & $\begin{array}{c}-536.06 * * * \\
(-3.48)\end{array}$ & $\begin{array}{l}-816.27 * * * \\
(-3.67)\end{array}$ \\
\hline CEO tenure & $\begin{array}{l}14.66^{* *} \\
(2.31)\end{array}$ & $\begin{array}{l}21.48 * * * \\
(3.54)\end{array}$ & $\begin{array}{l}-3.87 * * * \\
(-0.33)\end{array}$ \\
\hline Largest shareholder holds $>50 \%$ & $\begin{array}{l}377.32 * * * \\
(3.20)\end{array}$ & $\begin{array}{l}382.44 * * * \\
(3.34)\end{array}$ & $\begin{array}{l}320.82 * * \\
(1.97)\end{array}$ \\
\hline Checked & $\begin{array}{l}-40.92 \\
(-0.33)\end{array}$ & $\begin{array}{l}-54.32 \\
(-0.41)\end{array}$ & $\begin{array}{l}67.44 \\
(0.44)\end{array}$ \\
\hline Codetermination & $\begin{array}{r}182.72 \\
(0.35)\end{array}$ & $\begin{array}{r}545.53 \\
(1.11)\end{array}$ & $\begin{array}{r}-496.39 \\
(-0.55)\end{array}$ \\
\hline Stake executive board & $\begin{array}{c}0.43 \\
(0.10)\end{array}$ & $\begin{array}{c}-2.78 \\
(-0.60)\end{array}$ & $\begin{array}{c}3.19 \\
(0.46)\end{array}$ \\
\hline Stake supervisory board & $\begin{array}{c}-0.97 \\
(-0.35)\end{array}$ & $\begin{array}{l}-3.33 \\
(-1.06)\end{array}$ & $\begin{array}{l}-1.97 \\
(-0.55)\end{array}$ \\
\hline Ln (market capitalization) & $\begin{array}{l}70.27 \\
(0.99)\end{array}$ & $\begin{array}{r}169.20^{*} \\
(1.72)\end{array}$ & $\begin{array}{l}79.70 \\
(0.81)\end{array}$ \\
\hline Share price performance & $\begin{array}{r}103.53 \\
(1.06)\end{array}$ & $\begin{array}{r}144.86 \\
(1.39)\end{array}$ & $\begin{array}{l}64.03 \\
(0.49)\end{array}$ \\
\hline Tobin's Q & $\begin{array}{l}50.00 \\
(0.86)\end{array}$ & $\begin{array}{l}50.55 \\
(0.94)\end{array}$ & $\begin{array}{l}98.75 \\
(0.71)\end{array}$ \\
\hline$\underline{\text { Year dummies }}$ & yes & yes & yes \\
\hline $\mathrm{R}^{2}$ within & 0.354 & 0.426 & 0.318 \\
\hline $\mathrm{R}^{2}$ between & 0.000 & 0.300 & 0.115 \\
\hline $\mathrm{R}^{2}$ overall & 0.046 & 0.311 & 0.001 \\
\hline $\mathrm{N}$ & 413 & 301 & 238 \\
\hline
\end{tabular}


Table 9

\section{Determinants of director compensation}

This table shows the results of fixed effects regressions with per capita director compensation as the dependent variable. The variable director compensation is measured as the total compensation of the executive board in units of $€ 1,000$ divided by the number of executive board members in the respective year. The first column shows the independent variables. The variable Former CEO is on board (is chairman/is ordinary board member)is equal to one, if any supervisory board member (the chairman of the supervisory board/an ordinary supervisory board member) in the respective year was the CEO of the same company in at least one of the previous years between 1987 and 2006 or in 1985 or in 1982 and zero otherwise. Ln(number of directors) is defined as the natural logarithm of the number of supervisory board members. The variable largest shareholder holds $>50 \%$ is a dummy that is set to one for all firms with a largest shareholder holding at least $50 \%$ of the voting equity, and zero otherwise. The variable stake executive (supervisory) board measures the percentage of shares held by members of the executive (supervisory) board. A firm is said to be checked if the second largest shareholder holds at least $5 \%$ of the voting shares at the first tier. The variable codetermination is defined as the number of employee representatives divided by the number of supervisory board members in the respective year; board meetings is measured as the number of board meetings in the respective year; $\ln$ (market capitalization) is defined as the natural logarithm of the total market value of equity; $R O A$ is calculated as the ratio of earnings before interest and taxes to total assets; share price performance is computed as the annual change in the share price from the previous year, index-adjusted using the CDAX performance index and Tobin's $Q$ is defined as the market value of equity plus total assets minus the book value of equity, divided by total assets. The coefficient for constant is the average value of the fixed effects as obtained from Stata 11. Each cell shows the estimated coefficient and t-value (in parentheses). The superscripts *,**, and *** denote significance at the $10 \%, 5 \%$, and $1 \%$ levels, respectively.

\begin{tabular}{|c|c|c|c|c|}
\hline & (1) & $(2)$ & (3) & (4) \\
\hline \multirow[t]{2}{*}{ Constant } & -51.75 & -59.54 & -65.88 & $-73.42 *$ \\
\hline & $(-1.21)$ & $(-1.39)$ & $(-1.50)$ & $(-1.67)$ \\
\hline \multirow[t]{2}{*}{ Former CEO on board } & 4.01 & & 4.64 & \\
\hline & $(0.89)$ & & $(1.03)$ & \\
\hline \multirow[t]{2}{*}{ Former CEO is chairman } & & $8.45^{*}$ & & $9.57 *$ \\
\hline & & $(1.69)$ & & $(1.89)$ \\
\hline \multirow{2}{*}{$\begin{array}{l}\text { Former CEO is ordinary } \\
\text { board member }\end{array}$} & & -5.64 & & -5.15 \\
\hline & & $(-0.87)$ & & $(-0.80)$ \\
\hline \multirow[t]{2}{*}{ Ln (number of directors) } & -1.01 & -0.28 & 0.60 & 1.30 \\
\hline & $(-0.11)$ & $(-0.03)$ & $(0.06)$ & $(0.14)$ \\
\hline \multirow{2}{*}{$\begin{array}{l}\text { Largest shareholder holds } \\
>50 \%\end{array}$} & 6.33 & 6.25 & 5.05 & 4.97 \\
\hline & $(1.41)$ & $(1.39)$ & $(1.10)$ & $(1.09)$ \\
\hline \multirow[t]{2}{*}{ Stake executive board } & 0.08 & 0.09 & 0.10 & 0.10 \\
\hline & $(0.69)$ & $(0.71)$ & $(0.73)$ & $(0.76)$ \\
\hline \multirow[t]{2}{*}{ Stake supervisory board } & -0.08 & -0.09 & -0.08 & -0.09 \\
\hline & $(0.69)$ & $(-0.85)$ & $(-0.78)$ & $(-0.85)$ \\
\hline \multirow[t]{2}{*}{ Checked } & -3.21 & -3.47 & -2.52 & -2.70 \\
\hline & $(-0.67)$ & $(-0.72)$ & $(-0.52)$ & $(-0.55)$ \\
\hline \multirow[t]{2}{*}{ Codetermination } & -32.79 & $-36.00 *$ & $-37.09 *$ & $-40.48 *$ \\
\hline & $(-1.64)$ & $(-1.80)$ & $(-1.75)$ & $(-1.91)$ \\
\hline \multirow[t]{2}{*}{ Board meetings } & 0.70 & 0.71 & 0.43 & 0.43 \\
\hline & $(0.79)$ & $(0.79)$ & $(0.49)$ & $(0.48)$ \\
\hline \multirow[t]{2}{*}{ Ln (market capitalization) } & $6.40 * *$ & $6.94 * *$ & $7.43 * * *$ & $7.96 * * *$ \\
\hline & $(2.35)$ & $(2.54)$ & $(2.67)$ & $(2.86)$ \\
\hline \multirow[t]{2}{*}{ ROA } & 29.05 & 29.65 & & \\
\hline & $(1.35)$ & $(1.38)$ & & \\
\hline \multirow[t]{2}{*}{ Share price performance } & & & -0.06 & 0.08 \\
\hline & & & $(-0.02)$ & $(0.03)$ \\
\hline \multirow[t]{2}{*}{ Tobin's Q } & -2.42 & -2.43 & -1.43 & -1.44 \\
\hline & $(-1.25)$ & $(-1.26)$ & $(-0.70)$ & $(-0.71)$ \\
\hline Year dummies & yes & yes & yes & yes \\
\hline $\mathrm{R}^{2}$ within & 0.070 & 0.073 & 0.067 & 0.071 \\
\hline $\mathrm{R}^{2}$ between & 0.308 & 0.311 & 0.332 & 0.328 \\
\hline $\mathrm{R}^{2}$ overall & 0.184 & 0.193 & 0.200 & 0.204 \\
\hline $\mathrm{N}$ & 1198 & 1198 & 1195 & 1195 \\
\hline
\end{tabular}




\section{Table 10}

\section{Determinants of director compensation: Difference in differences}

This table shows the results of fixed effects regressions using the difference-in-differences methodology with per capita director compensation as the dependent variable and the last two years prior to and the first five year following unforced CEO turnovers as observations. The variable director compensation is measured as the total compensation of the supervisory board in units of $€ 1,000$ divided by the number of supervisory board members. The first column shows the independent variables. The variable post is equal to one for observations in the twoyear period prior to the CEO turnover, and zero otherwise. Post*treatment measures the difference between the differences of executive compensation before and after CEO turnover for the treatment and control groups. The control group consists of all firms whose former CEO leaves the firm. For columns $1(2 / 3)$ the treatment group consists of all firms whose former CEO transfers to the supervisory board (becomes the chairman of the supervisory board/becomes an ordinary supervisory board member). Ln(number of directors) is defined as the natural logarithm of the number of supervisory board members. The variable largest shareholder holds $>50 \%$ is a dummy that is set to one for all firms with a largest shareholder holding at least $50 \%$ of the voting equity, and zero otherwise. The variable stake executive (supervisory) board measures the percentage of shares held by members of the executive (supervisory) board. A firm is said to be checked if the second largest shareholder holds at least $5 \%$ of the voting shares at the first tier. The variable codetermination is defined as the number of employee representatives divided by the number of supervisory board members in the respective year; $\ln ($ market capitalization) is defined as the natural logarithm of the total market value of equity; share price performance is computed as the annual change in the share price from the previous year, index-adjusted using the CDAX performance index and Tobin's $Q$ is defined as the market value of equity plus total assets minus the book value of equity, divided by total assets. The coefficient for constant is the average value of the fixed effects as obtained from Stata 11. Each cell shows the estimated coefficient and t-value (in parentheses). The superscripts *,**, and *** denote significance at the $10 \%, 5 \%$, and $1 \%$ levels, respectively.

\begin{tabular}{|c|c|c|c|}
\hline & $\begin{array}{c}\text { Former CEO changes to } \\
\text { the supervisory board }\end{array}$ & $\begin{array}{l}\text { Former CEO becomes } \\
\text { chairman of the board }\end{array}$ & $\begin{array}{l}\text { Former CEO becomes } \\
\text { ordinary board member }\end{array}$ \\
\hline & $(1)$ & $(2)$ & (3) \\
\hline \multirow[t]{2}{*}{ Constant } & -124.74 & $-192.94 * *$ & -20.42 \\
\hline & $(-1.47)$ & $(-2.26)$ & $(-0.25)$ \\
\hline \multirow[t]{2}{*}{ Post } & -2.68 & 2.91 & 3.30 \\
\hline & $(-0.33)$ & $(0.44)$ & $(0.31)$ \\
\hline \multirow{2}{*}{ Post*treatment } & 7.11 & 8.69 & 2.93 \\
\hline & $(1.00)$ & $(1.42)$ & $(0.30)$ \\
\hline \multirow[t]{2}{*}{$\operatorname{Ln}$ (number of directors) } & -0.73 & 8.89 & 3.28 \\
\hline & $(-0.05)$ & $(0.68)$ & $(0.13)$ \\
\hline \multirow[t]{2}{*}{ Largest shareholder holds $>50 \%$} & -6.17 & -3.74 & -6.08 \\
\hline & $(-1.07)$ & $(-0.75)$ & $(-0.76)$ \\
\hline \multirow[t]{2}{*}{ Stake executive board } & 0.25 & 0.28 & 0.27 \\
\hline & $(1.20)$ & $(1.38)$ & $(0.78)$ \\
\hline \multirow[t]{2}{*}{ Stake supervisory board } & -0.07 & 0.02 & -0.12 \\
\hline & $(-0.49)$ & $(0.13)$ & $(-0.63)$ \\
\hline \multirow[t]{2}{*}{ Checked } & 3.59 & 7.56 & 4.88 \\
\hline & $(0.60)$ & $(1.33)$ & $(0.64)$ \\
\hline \multirow[t]{2}{*}{ Codetermination } & -41.37 & -35.27 & -60.97 \\
\hline & $(-1.52)$ & $(-1.56)$ & $(-1.21)$ \\
\hline \multirow[t]{2}{*}{ Ln (market capitalization) } & $8.16^{* * *}$ & $10.07 * * *$ & 4.99 \\
\hline & $(2.57)$ & $(3.00)$ & (1.19) \\
\hline \multirow[t]{2}{*}{ Share price performance } & 0.05 & -3.49 & -0.08 \\
\hline & $(0.01)$ & $(-0.85)$ & $(-0.01)$ \\
\hline \multirow[t]{2}{*}{ Tobin's Q } & -0.50 & 0.41 & 3.46 \\
\hline & $(-0.17)$ & $(0.17)$ & $(0.63)$ \\
\hline Year dummies & yes & yes & yes \\
\hline $\mathrm{R}^{2}$ within & 0.257 & 0.411 & 0.181 \\
\hline $\mathrm{R}^{2}$ between & 0.412 & 0.554 & 0.145 \\
\hline $\mathrm{R}^{2}$ overall & 0.363 & 0.521 & 0.159 \\
\hline $\mathrm{N}$ & 427 & 315 & 252 \\
\hline
\end{tabular}


CFR Working Paper Series

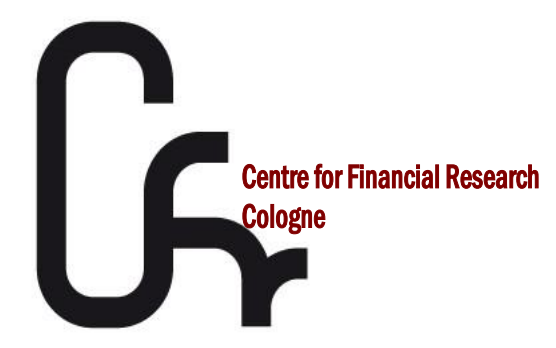

CFR Working Papers are available for download from www.cfr-cologne.de.

Hardcopies can be ordered from: Centre for Financial Research (CFR), Albertus Magnus Platz, 50923 Koeln, Germany.

2013

No. $\quad$ Author(s) Title

13-02 C. Andres, A. Betzer, M. Open Market Share Repurchases in Germany: A Conditional Doumet, E. Theissen Event Study Approach

13-01 J. Gaul, E. Theissen A Partially Linear Approach to Modelling the Dynamics of Spot and Futures Prices

2012

\begin{tabular}{|c|c|c|}
\hline No. & Author(s) & Title \\
\hline $12-12$ & $\begin{array}{l}\text { Y. Gündüz, J. Nasev, } \\
\text { M. Trapp }\end{array}$ & The Price Impact of CDS Trading \\
\hline $12-11$ & $\begin{array}{l}\text { Y. Wu, R. Wermers, } \\
\text { J. Zechner }\end{array}$ & $\begin{array}{l}\text { Governance and Shareholder Value in Delegated Portfolio } \\
\text { Management: The Case of Closed-End Funds }\end{array}$ \\
\hline $12-10$ & M. Trapp, C. Wewel & Transatlantic Systemic Risk \\
\hline $12-09$ & $\begin{array}{l}\text { G. Cici, A. Kempf, } \\
\text { C. Sorhage }\end{array}$ & $\begin{array}{l}\text { Are Financial Advisors Useful? Evidence from Tax-Motivated } \\
\text { Mutual Fund Flows }\end{array}$ \\
\hline $12-08$ & S. Jank & $\begin{array}{l}\text { Changes in the composition of publicly traded firms: } \\
\text { Implications for the dividend-price ratio and return predictability }\end{array}$ \\
\hline $12-07$ & G. Cici, C. Rosenfeld & The Investment Abilities of Mutual Fund Buy-Side Analysts \\
\hline $12-06$ & $\begin{array}{l}\text { A. Kempf, A. Pütz, } \\
\text { F. Sonnenburg }\end{array}$ & $\begin{array}{l}\text { Fund Manager Duality: Impact on Performance and Investment } \\
\text { Behavior }\end{array}$ \\
\hline $12-05$ & R. Wermers & Runs on Money Market Mutual Funds \\
\hline $12-04$ & R. Wermers & $\begin{array}{l}\text { A matter of style: The causes and consequences of style drift } \\
\text { in institutional portfolios }\end{array}$ \\
\hline $12-03$ & $\begin{array}{l}\text { C. Andres, A. Betzer, I. } \\
\text { van den Bongard, C. } \\
\text { Haesner, E. Theissen }\end{array}$ & $\begin{array}{l}\text { Dividend Announcements Reconsidered: } \\
\text { Dividend Changes versus Dividend Surprises }\end{array}$ \\
\hline
\end{tabular}


Should I Stay or Should I Go?

12-01 L. Andreu, A. Pütz

Former CEOs as Monitors

Are Two Business Degrees Better Than One?

Evidence from Mutual Fund Managers' Education

\section{1}

\begin{tabular}{|c|c|c|}
\hline No. & Author(s) & Title \\
\hline $11-16$ & $\begin{array}{l}\text { V. Agarwal, J.-P. Gómez, } \\
\text { R. Priestley }\end{array}$ & $\begin{array}{l}\text { Management Compensation and Market Timing under Portfolio } \\
\text { Constraints }\end{array}$ \\
\hline $11-15$ & T. Dimpfl, S. Jank & $\begin{array}{l}\text { Can Internet Search Queries Help to Predict Stock Market } \\
\text { Volatility? }\end{array}$ \\
\hline $11-14$ & $\begin{array}{l}\text { P. Gomber, } \\
\text { U. Schweickert, } \\
\text { E. Theissen }\end{array}$ & $\begin{array}{l}\text { Liquidity Dynamics in an Electronic Open Limit Order Book: } \\
\text { An Event Study Approach }\end{array}$ \\
\hline $11-13$ & D. Hess, S. Orbe & $\begin{array}{l}\text { Irrationality or Efficiency of Macroeconomic Survey Forecasts? } \\
\text { Implications from the Anchoring Bias Test }\end{array}$ \\
\hline $11-12$ & D. Hess, P. Immenkötter & Optimal Leverage, its Benefits, and the Business Cycle \\
\hline $11-11$ & $\begin{array}{l}\text { N. Heinrichs, D. Hess, } \\
\text { C. Homburg, M. Lorenz, } \\
\text { S. Sievers }\end{array}$ & $\begin{array}{l}\text { Extended Dividend, Cash Flow and Residual Income Valuation } \\
\text { Models - Accounting for Deviations from Ideal Conditions }\end{array}$ \\
\hline $11-10$ & $\begin{array}{l}\text { A. Kempf, O. Korn, } \\
\text { S. Saßning }\end{array}$ & Portfolio Optimization using Forward - Looking Information \\
\hline $11-09$ & V. Agarwal, S. Ray & $\begin{array}{l}\text { Determinants and Implications of Fee Changes in the Hedge } \\
\text { Fund Industry }\end{array}$ \\
\hline $11-08$ & G. Cici, L.-F. Palacios & $\begin{array}{l}\text { On the Use of Options by Mutual Funds: Do They Know What } \\
\text { They Are Doing? }\end{array}$ \\
\hline $11-07$ & $\begin{array}{l}\text { V. Agarwal, G. D. Gay, } \\
\text { L. Ling }\end{array}$ & $\begin{array}{l}\text { Performance inconsistency in mutual funds: An investigation of } \\
\text { window-dressing behavior }\end{array}$ \\
\hline $11-06$ & $\begin{array}{l}\text { N. Hautsch, D. Hess, } \\
\text { D. Veredas }\end{array}$ & $\begin{array}{l}\text { The Impact of Macroeconomic News on Quote Adjustments, } \\
\text { Noise, and Informational Volatility }\end{array}$ \\
\hline $11-05$ & G. Cici & $\begin{array}{l}\text { The Prevalence of the Disposition Effect in Mutual Funds' } \\
\text { Trades }\end{array}$ \\
\hline $11-04$ & S. Jank & Mutual Fund Flows, Expected Returns and the Real Economy \\
\hline $11-03$ & G.Fellner, E.Theissen & $\begin{array}{l}\text { Short Sale Constraints, Divergence of Opinion and Asset } \\
\text { Value: Evidence from the Laboratory }\end{array}$ \\
\hline $11-02$ & S.Jank & Are There Disadvantaged Clienteles in Mutual Funds? \\
\hline $11-01$ & V. Agarwal, C. Meneghetti & The Role of Hedge Funds as Primary Lenders \\
\hline
\end{tabular}

\section{0}

No. Author(s) Title 
10-19

J. Hengelbrock,

E. Theissen, C. Westheide

10-18

G. Cici, S. Gibson

10-17 D. Hess, D. Kreutzmann,

O. Pucker

10-16

S. Jank, M. Wedow

10-15

G. Cici, A. Kempf, A. Puetz

10-14

10-13

J. Grammig, S. Jank

S. Jank, M. Wedow

10-12 S. Artmann, P. Finter,

A. Kempf, S. Koch,

E. Theissen

10-11 M. Chesney, A. Kempf

10-10

S. Frey, P. Herbst

10-09 V. Agarwal, W. Jiang,

Y. Tang, B. Yang

10-08 V. Agarwal, V. Fos, W. Jiang

10-07 V. Agarwal, G. Bakshi, J. Huij

10-06 J. Grammig, F. J. Peter

10-05 K. Drachter, A. Kempf

10-04 J. Fang, A. Kempf, M. Trapp

10-03 P. Finter, A. NiessenRuenzi, S. Ruenzi

10-02 D. Hunter, E. Kandel,

S. Kandel, R. Wermers

10-01 S. Artmann, P. Finter, A. Kempf
Market Response to Investor Sentiment

The Performance of Corporate-Bond Mutual Funds:

Evidence Based on Security-Level Holdings

Projected Earnings Accuracy and the Profitability of Stock Recommendations

Sturm und Drang in Money Market Funds: When Money Market Funds Cease to Be Narrow

The Valuation of Hedge Funds' Equity Positions

Creative Destruction and Asset Prices

Purchase and Redemption Decisions of Mutual Fund Investors and the Role of Fund Families

The Cross-Section of German Stock Returns:

New Data and New Evidence

The Value of Tradeability

The Influence of Buy-side Analysts on

Mutual Fund Trading

Uncovering Hedge Fund Skill from the Portfolio Holdings They Hide

Inferring Reporting Biases in Hedge Fund Databases from Hedge Fund Equity Holdings

Do Higher-Moment Equity Risks Explain Hedge Fund Returns?

Tell-Tale Tails

Höhe, Struktur und Determinanten der ManagervergütungEine Analyse der Fondsbranche in Deutschland

Fund Manager Allocation

The Impact of Investor Sentiment on the German Stock Market

Endogenous Benchmarks

Determinants of Expected Stock Returns: Large Sample Evidence from the German Market

2009

No.

Author(s)

Title

$09-17$

E. Theissen

Price Discovery in Spot and Futures Markets:

A Reconsideration

09-16 M. Trapp

Trading the Bond-CDS Basis - The Role of Credit Risk

09-15 A. Betzer, J. Gider, and Liquidity

D.Metzger, E. Theissen

Strategic Trading and Trade Reporting by Corporate Insiders 
$09-14$

A. Kempf, O. Korn,

M. Uhrig-Homburg

$09-13$

W. Bühler, M. Trapp

09-12 W. Bühler, M. Trapp

09-11 S. J. Taylor, P. K. Yadav, Y. Zhang

09-10 A. Kempf, C. Merkle,

A. Niessen-Ruenzi

09-09 V. Fotak, V. Raman,

P. K. Yadav

09-08 F. Bardong, S.M. Bartram, P.K. Yadav

09-07 S. J. Taylor, P. K. Yadav, Y. Zhang

09-06

S. Frey, P. Sandas

09-05

H. Beltran-Lopez, P. Giot,

J. Grammig

09-04 J. Fang, S. Ruenzi

09-03 A. Banegas, B. Gillen,

A. Timmermann,

R. Wermers

09-02

09-01
J. Grammig, A. Schrimpf, M. Schuppli

O. Korn, P. Koziol
The Term Structure of Illiquidity Premia

Time-Varying Credit Risk and Liquidity Premia in Bond and CDS Markets

Explaining the Bond-CDS Basis - The Role of Credit Risk and Liquidity

Cross-sectional analysis of risk-neutral skewness

Low Risk and High Return - Affective Attitudes and Stock Market Expectations

Naked Short Selling: The Emperor`s New Clothes?

Informed Trading, Information Asymmetry and Pricing of Information Risk: Empirical Evidence from the NYSE

The information content of implied volatilities and model-free volatility expectations: Evidence from options written on individual stocks

The Impact of Iceberg Orders in Limit Order Books

Commonalities in the Order Book

Rapid Trading bei deutschen Aktienfonds:

Evidenz aus einer großen deutschen Fondsgesellschaft

The Cross-Section of Conditional Mutual Fund Performance in European Stock Markets

Long-Horizon Consumption Risk and the Cross-Section of Returns: New Tests and International Evidence

The Term Structure of Currency Hedge Ratios

2008

\begin{tabular}{|c|c|c|}
\hline No. & Author(s) & Title \\
\hline $08-12$ & $\begin{array}{l}\text { U. Bonenkamp, } \\
\text { C. Homburg, A. Kempf }\end{array}$ & Fundamental Information in Technical Trading Strategies \\
\hline $08-11$ & O. Korn & Risk Management with Default-risky Forwards \\
\hline $08-10$ & J. Grammig, F.J. Peter & $\begin{array}{l}\text { International Price Discovery in the Presence } \\
\text { of Market Microstructure Effects }\end{array}$ \\
\hline 08-09 & C. M. Kuhnen, A. Niessen & Public Opinion and Executive Compensation \\
\hline 08-08 & A. Pütz, S. Ruenzi & $\begin{array}{l}\text { Overconfidence among Professional Investors: Evidence from } \\
\text { Mutual Fund Managers }\end{array}$ \\
\hline $08-07$ & P. Osthoff & What matters to SRI investors? \\
\hline 08-06 & A. Betzer, E. Theissen & $\begin{array}{l}\text { Sooner Or Later: Delays in Trade Reporting by Corporate } \\
\text { Insiders }\end{array}$ \\
\hline 08-05 & P. Linge, E. Theissen & $\begin{array}{l}\text { Determinanten der Aktionärspräsenz auf } \\
\text { Hauptversammlungen deutscher Aktiengesellschaften }\end{array}$ \\
\hline 08-04 & N. Hautsch, D. Hess, & Price Adjustment to News with Uncertain Precision \\
\hline
\end{tabular}



C. Müller
08-03 D. Hess, H. Huang,
How Do Commodity Futures Respond to Macroeconomic
A. Niessen
News?
08-02 R. Chakrabarti,
W. Megginson, P. Yadav
Corporate Governance in India
08-01 C. Andres, E. Theissen
Setting a Fox to Keep the Geese - Does the Comply-or-Explain Principle Work?

2007

\begin{tabular}{|c|c|c|}
\hline No. & Author(s) & Title \\
\hline 07-16 & $\begin{array}{l}\text { M. Bär, A. Niessen, } \\
\text { S. Ruenzi }\end{array}$ & $\begin{array}{l}\text { The Impact of Work Group Diversity on Performance: } \\
\text { Large Sample Evidence from the Mutual Fund Industry }\end{array}$ \\
\hline 07-15 & A. Niessen, S. Ruenzi & $\begin{array}{l}\text { Political Connectedness and Firm Performance: } \\
\text { Evidence From Germany }\end{array}$ \\
\hline $07-14$ & O. Korn & Hedging Price Risk when Payment Dates are Uncertain \\
\hline $07-13$ & A. Kempf, P. Osthoff & SRI Funds: Nomen est Omen \\
\hline 07-12 & $\begin{array}{l}\text { J. Grammig, E. Theissen, } \\
\text { O. Wuensche }\end{array}$ & Time and Price Impact of a Trade: A Structural Approach \\
\hline $07-11$ & V. Agarwal, J. R. Kale & $\begin{array}{l}\text { On the Relative Performance of Multi-Strategy and Funds of } \\
\text { Hedge Funds }\end{array}$ \\
\hline 07-10 & $\begin{array}{l}\text { M. Kasch-Haroutounian, } \\
\text { E. Theissen }\end{array}$ & Competition Between Exchanges: Euronext versus Xetra \\
\hline 07-09 & $\begin{array}{l}\text { V. Agarwal, N. D. Daniel, } \\
\text { N. Y. Naik }\end{array}$ & Do hedge funds manage their reported returns? \\
\hline 07-08 & $\begin{array}{l}\text { N. C. Brown, K. D. Wei, } \\
\text { R. Wermers }\end{array}$ & $\begin{array}{l}\text { Analyst Recommendations, Mutual Fund Herding, and } \\
\text { Overreaction in Stock Prices }\end{array}$ \\
\hline $07-07$ & A. Betzer, E. Theissen & $\begin{array}{l}\text { Insider Trading and Corporate Governance: } \\
\text { The Case of Germany }\end{array}$ \\
\hline 07-06 & V. Agarwal, L. Wang & Transaction Costs and Value Premium \\
\hline 07-05 & J. Grammig, A. Schrimpf & $\begin{array}{l}\text { Asset Pricing with a Reference Level of Consumption: } \\
\text { New Evidence from the Cross-Section of Stock Returns }\end{array}$ \\
\hline $07-04$ & $\begin{array}{l}\text { V. Agarwal, N.M. Boyson, } \\
\text { N.Y. Naik }\end{array}$ & $\begin{array}{l}\text { Hedge Funds for retail investors? } \\
\text { An examination of hedged mutual funds }\end{array}$ \\
\hline $07-03$ & D. Hess, A. Niessen & $\begin{array}{l}\text { The Early News Catches the Attention: } \\
\text { On the Relative Price Impact of Similar Economic Indicators }\end{array}$ \\
\hline 07-02 & $\begin{array}{l}\text { A. Kempf, S. Ruenzi, } \\
\text { T. Thiele }\end{array}$ & $\begin{array}{l}\text { Employment Risk, Compensation Incentives and Managerial } \\
\text { Risk Taking - Evidence from the Mutual Fund Industry - }\end{array}$ \\
\hline $07-01$ & M. Hagemeister, A. Kempf & $\begin{array}{l}\text { CAPM und erwartete Renditen: Eine Untersuchung auf Basis } \\
\text { der Erwartung von Marktteilnehmern }\end{array}$ \\
\hline
\end{tabular}

\section{6}

No. Author(s) Title

06-13 S. Čeljo-Hörhager,

A. Niessen

How do Self-fulfilling Prophecies affect Financial Ratings? - An experimental study 
06-12 R. Wermers, Y. Wu, J. Zechner

06-11 U. v. Lilienfeld-Toal,

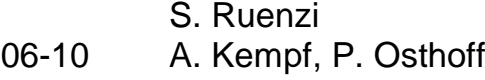

06-09 R. Wermers, T. Yao, J. Zhao

06-08 M. Hoffmann, B. Kempa

06-07 K. Drachter, A. Kempf, M. Wagner

06-06 J.P. Krahnen, F.A. Schmid, E. Theissen

06-05 S. Ber, S. Ruenzi

06-04 A. Kempf, D. Mayston

06-03 O. Korn, C. Koziol

06-02 O. Scaillet, L. Barras, R. Wermers

06-01 A. Niessen, S. Ruenzi
Portfolio Performance, Discount Dynamics, and the Turnover of Closed-End Fund Managers

Why Managers Hold Shares of Their Firm: An Empirical

Analysis

The Effect of Socially Responsible Investing on Portfolio Performance

Extracting Stock Selection Information from Mutual Fund holdings: An Efficient Aggregation Approach

The Poole Analysis in the New Open Economy

Macroeconomic Framework

Decision Processes in German Mutual Fund Companies:

Evidence from a Telephone Survey

Investment Performance and Market Share: A Study of the German Mutual Fund Industry

On the Usability of Synthetic Measures of Mutual Fund NetFlows

Liquidity Commonality Beyond Best Prices

Bond Portfolio Optimization: A Risk-Return Approach

False Discoveries in Mutual Fund Performance: Measuring Luck in Estimated Alphas

Sex Matters: Gender Differences in a Professional Setting

\section{5}

No.

Author(s)

E. Theissen

05-15 T. Foucault, S. Moinas, E. Theissen

05-14

R. Kosowski,

A. Timmermann,

R. Wermers, H. White

05-12

D. Avramov, R. Wermers

05-11

K. Griese, A. Kempf

S. Ber, A. Kempf,

S. Ruenzi

05-10

M. Bär, A. Kempf,

S. Ruenzi

05-09

M. Hoffmann

05-08

S. Ruenzi

05-07

A. Kempf, S. Ruenzi

05-06

J. Grammig, E. Theissen

05-05

H. Beltran-Lopez, J. Grammig, A.J. Menkveld

05-04 M. Hoffmann
Title

An Analysis of Private Investors' Stock Market Return Forecasts

Does Anonymity Matter in Electronic Limit Order Markets

Can Mutual Fund „Stars“ Really Pick Stocks?

New Evidence from a Bootstrap Analysis

Investing in Mutual Funds when Returns are Predictable

Liquiditätsdynamik am deutschen Aktienmarkt

Determinanten der Mittelzuflüsse bei deutschen Aktienfonds

Is a Team Different From the Sum of Its Parts?

Evidence from Mutual Fund Managers

Saving, Investment and the Net Foreign Asset Position

Mutual Fund Growth in Standard and Specialist Market Segments

Status Quo Bias and the Number of Alternatives - An Empirical Illustration from the Mutual Fund Industry

Is Best Really Better? Internalization of Orders in an Open Limit Order Book

Limit order books and trade informativeness

Compensating Wages under different Exchange rate Regimes 
Fixed versus Flexible Exchange Rates: Evidence from Developing Countries

05-02

A. Kempf, C. Memmel

Estimating the Global Minimum Variance Portfolio

05-01

S. Frey, J. Grammig

Liquidity supply and adverse selection in a pure limit order book market

\section{4}

No.

Author(s)

Title

$04-10$

N. Hautsch, D. Hess

Bayesian Learning in Financial Markets - Testing for the Relevance of Information Precision in Price Discovery

04-09 A. Kempf, K. Kreuzberg

Portfolio Disclosure, Portfolio Selection and Mutual Fund Performance Evaluation

04-08 N.F. Carline, S.C. Linn, P.K. Yadav

Operating performance changes associated with corporate mergers and the role of corporate governance

04-07 J.J. Merrick, Jr., N.Y. Naik, Strategic Trading Behaviour and Price Distortion in a P.K. Yadav Manipulated Market: Anatomy of a Squeeze

04-06 N.Y. Naik, P.K. Yadav

Trading Costs of Public Investors with Obligatory and Voluntary Market-Making: Evidence from Market Reforms

04-05 A. Kempf, S. Ruenzi

Family Matters: Rankings Within Fund Families and Fund Inflows

04-04 V. Agarwal, N.D. Daniel, N.Y. Naik

Role of Managerial Incentives and Discretion in Hedge Fund Performance

04-03 V. Agarwal, W.H. Fung,

Risk and Return in Convertible Arbitrage: J.C. Loon, N.Y. Naik Evidence from the Convertible Bond Market

04-02 A. Kempf, S. Ruenzi

Tournaments in Mutual Fund Families

04-01 I. Chowdhury, M. Inflation Dynamics and the Cost Channel of Monetary Hoffmann, A. Schabert Transmission 
